\title{
17- KKTC Türkçe ders kitaplarındaki etkinliklerin Yenilenmiş Bloom Sınıflandırması'na göre incelenmesi: 6. sınıf Türkçe ders kitabı örneği
}

Bünyamin SARIKAYA ${ }^{1}$

Yunus ŞAKİROĞLU ${ }^{2}$

APA: Sarıkaya, B.; Şakiroğlu, Y. (2021). KKTC Türkçe ders kitaplarındaki etkinliklerin Yenilenmiş Bloom Sinıflandırması'na göre incelenmesi: 6. sınıf Türkçe ders kitabı örneği. RumeliDE Dil ve Edebiyat Araştırmaları Dergisi, (25), 273-296. DOI: 10.2900o/rumelide.1036520.

\section{Öz}

$\mathrm{Bu}$ çalışmanın amacı, KKTC Türkçe ders kitaplarındaki etkinliklerin Yenilenmiş Bloom Sinıflandırması'na göre incelenmesidir. Bu amaç doğrultusunda KKTC 6. sınıf Türkçe ders kitabındaki okuma metinlerinde yer alan etkinlikler Yenilenmiş Bloom Sınıflandırması'nın hatırlama, anlama, uygulama, çözümleme, değerlendirme ve yaratma basamaklarına göre ele alınmıştır. Nitel araştırma yöntemlerinden doküman incelemesinin kullanıldığı çalışmada veriler betimsel analiz yöntemi ile çözümlenmiş ve ihtiyaç duyulan her aşamada uzman görüşlerine başvurulmuştur. Çalışmanın materyalini KKTC Milli Eğitim ve Kültür Bakanlığı tarafından 2018 yılında yayımlanan "Türkçe 6. Sınıf 1. Kitap" oluşturmaktadır. KKTC Türkçe dersleri, her sınıf düzeyinde 2 ayrı kitaptan oluşmaktadır. Bu çalışmada da Türkçe 6. Sınıf 1. Kitap’taki okuma metinlerinde yer alan etkinlikler değerlendirilmiştir. İlgili kitap 3 tema ve her temada yer alan 5 okuma ve 1 serbest okuma metninden oluşmaktadır. KKTC Türkçe 6. sınıf 1 . ders kitabında toplam 95 etkinliğin yer aldığı ve bunlardan 57'sinin tür çalışmasına, 38’inin ise dil bilgisi çalışmalarına yönelik olduğu saptanmıştır. Etkinliklerin Yenilenmiş Bloom Sınıflandırması'na göre dağılımı incelendiğinde hem tür hem de dil bilgisi çalışmalarının büyük kısmının hatırlama, anlama ve yaratma basamaklarına uygun olduğu ancak çözümleme basamağına uygun hiçbir etkinliğin olmadığı tespit edilmiştir. Çalışmada ulaşılan bulgular alan yazında benzer konuda yapılmış çalışmaların sonuçlarıyla tartışılmış ve bu bağlamda alan yazına katkı sunacağı düşünülen önerilerde bulunulmuştur.

Anahtar kelimeler: KKTC Türkçe ders kitapları, Yenilenmiş Bloom Sınıflandırması, metin, etkinlik

\section{An examination of activities in TRNC Turkish textbooks according to Bloom's Revised Taxonomy: An example of sixth grade turkish textbook}

\begin{abstract}
This study investigated the activities in Turkish textbooks in the Turkish Republic of Northern Cyprus (TRNC) according to Bloom's Revised Taxonomy. To that end, the study addressed the activities in the reading texts in the TRNC sixth-grade Turkish textbook in terms of six levels of Bloom's Revised Taxonomy; remembering, understanding, applying, analyzing, evaluating, and creating. The study
\end{abstract}

Doç. Dr., Muş Alparslan Üniversitesi, Eğitim Fakültesi, Türkçe ve Sosyal Bilimler Eğitimi Bölümü, Türkçe Eğitimi ABD (Muş, Türkiye), b.sarikaya@alparslan.edu.tr, ORCID ID: 000o-0002-8393-7127 [Araştırma makalesi, Makale kayıt tarihi: 09.11.2021-kabul tarihi: 20.12.2021; DOI: 10.29000/rumelide.1036520]

Arş. Gör., Muş Alparslan Üniversitesi, Eğitim Fakültesi, Türkçe ve Sosyal Bilimler Eğitimi Bölümü, Türkçe Eğitimi ABD (Muş, Türkiye), y.sakiroglu@alparslan.edu.tr, ORCID ID: 0000-0001-6151-7984

Adres

RumeliDE Dil ve Edebiyat Araştırmaları Dergisi $\quad$ RumeliDE Journal of Language and Literature Studies Osmanağa Mahallesi, Mürver Çiçeği Sokak, No:14/8 Osmanağa Mahallesi, Mürver Çiçeği Sokak, No:14/8 Kadıköy - ÍSTANBUL / TÜRKIYE 34714 Kadıköy - ISTANBUL / TURKEY 34714 e-posta: editor@rumelide.com e-mail: editor@rumelide.com, tel: +90 505 7958124, +90 2167730616 phone: +90 505 7958124, +90 2167730616 
adopted a document analysis, which is a qualitative research method. The data were analyzed using descriptive analysis, and experts were consulted when needed. The study material was the "sixthgrade Turkish book 1" published by the Ministry of National Education and Culture of the TRNC in 2018. TRNC Turkish lessons consist of two books for each grade level. This study focused on the activities in the reading texts in the sixth-grade Turkish book 1. The book has three themes, each consisting of five readingtexts and one free reading text. The results showed that the book had 95 activities. Fifty-seven activities were concentrated on genre study, while 38 focused on grammar. Most activities agreed with the "remembering," "understanding," and "creating" steps of Bloom's Revised Taxonomy, but none of the activities was suitable for the "analyzing” step of Bloom's Revised Taxonomy. The results were discussed in reference to similar studies, and recommendations were made accordingly.

Keywords: TRNC Turkish textbooks, Bloom's Revised Taxonomy, text, activity

\section{Giriș}

Öğretim programlarına hizmet eden, programın ögeleri arasında bulunan ölçme ve değerlendirme ögesinin en önemli aracı olan ders ve çalışma kitaplarının, eğitimi şekillendirecek müdahalelerden ayrı tutulması söz konusu edilemez. Bu müdahalelerden birisi de "birey davranışlarının istendik yönde değişimi üzerine odaklanan eğitimin, bu amaca ulaşması için davranışların belirli özellikler altında belirli sınıflamalara tabi tutulması"dır (Yeşilyurt, 2012).

Bloom Sınıflandırması yayımlandığı günden bu yana üst düzey düşünme becerilerinin etkili şekilde kullanılmasına yönelik eğitim programlarının tasarlanması ve yürütülmesinde önemli katkılar sağlayan bir sinıflandırmadır (Arı, 2011; Bekdemir ve Selim, 2008; Wineburg ve Schneider, 2013). Hemen hemen tüm dünyada öğretim programlarının kazanımları ve ölçme-değerlendirme yöntemleri, Bloom'un Sınıflandırması ile oluşturulmuş veya sınanmıştır. 1956'da tamamlanıp yayımlanan Bloom Sınıflandırması altı seviyeden oluşmaktadır. Uygulama dışındaki diğer ana kategoriler, alt kategorilere de bölünmüştür. İlk Bloom Sınıflandırmasının en alt basamağında bilgi seviyesi vardır. Bu seviyeden daha üst seviyelere doğru çlkıldıkça sırayla; kavrama, uygulama, analiz, sentez ve değerlendirme basamakları birbiri ardına gelmektedir. Bilgi, kavrama, uygulama basamakları alt bilişsel seviyeler olarak kabul edilirken; analiz, sentez, değerlendirme, üstbilişsel seviyeler olarak kabul edilir (Bloom ve ark., 1956; Anderson ve Krathwohl, 2001; Krathwohl, 2002).

Basamaklar basitten karmaşığa doğru sıralanmaktadır (Bloom ve diğerleri, 1956; Krathwohl, 2002; Bümen, 2007; Başbay, 2008; Demir, 2015). Çok uzun yllar kullanılan orijinal sınıflandırma; alt basamaklar gerçekleştirilmeden üst basamakların gerçekleştirilememesi, sentez basamağının değerlendirme basamağını da kapsıyor olması şeklinde bazı eleştiriler almıştır. Yapılandırmacı yaklaşımın ön gördüğü öğrenci merkezli eğitim, ön planda olan bir aktif öğrenme, etkin bireysel katılım, öğrenenin öğrenme sorumluluğunu üstlenmesi, bilginin keşfedilip yapılandırılması gibi becerileri kendi

yapısı ile bütünleştirememiştir. Bloom'un geliştirdiği sınıflandırma yaklaşımı ile yapısalcı yaklaşımın ölçülmesini istediği üst düzey zihinsel beceriler de tam anlamıyla ölçülememiştir (Anderson ve Krathwohl, 2001; Amer, 2006; Ayvacı ve Türkdoğan, 2010; Arı, 2011). Ayrıca "aradan geçen zamanda teknoloji ve diğer alanlardaki gelişme ve değişime uyarlanması ihtiyacı” (Beyreli ve Sönmez, 2017: 216) da değişikliği kaçınılmaz kılmıştır.

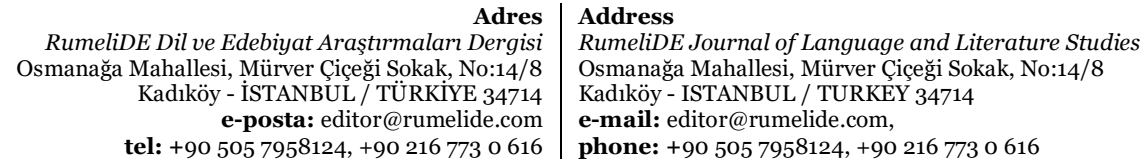


Yenilenen sınıflandırmada hatırlama, anlama, uygulama basamakları birikerek çoğalan (kümülatif) bir hiyerarşi olmaktan çıkarılmış; sadece bazı basamaklar arasında (kavrama, uygulama ve analiz) kümülatif hiyerarşi olduğu belirtilmiştir. Ayrıca kavrama ve sentez basamaklarının isimleri ve yaratma/sentez ile değerlendirme basamaklarının sıraları değiştirilmiştir (Bümen, 2006). Buna göre Bloom Sınıflandırması ile Yenilenmiş Bloom Sınıflandırmasındaki bilişsel alan basamaklarının sınıflandırılması Tablo 1'de gösterilmiştir.

Tablo 1. Bloom Sınıflandırması ile Yenilenmiş Bloom Sınıflandırması bilişsel alan basamakları

\begin{tabular}{ll}
\hline Bloom Sınıflandırması & Yenilenmiş Bloom Sınıflandırması \\
\hline Bilgi & Hatırlama \\
\hline Kavrama & Anlama \\
\hline Uygulama & Uygulama \\
\hline Analiz & Çözümleme \\
\hline Sentez & Değerlendirme \\
\hline Değerlendirme & Yaratma \\
\hline
\end{tabular}

Tablo 1 incelendiğinde ilk Bloom Sınıflandırması'nda yer alan isim ifadelerinin Yenilenmiş Bloom Sinıflandırmasında fiil formuna dönüştürüldüğü görülmektedir. Ayrıca ilk taksonomideki "Bilgi" yerine "Hatırlama”, "Kavrama” yerine "Anlama”, "Analiz" yerine "Çözümleme”, "Sentez” yerine "Yaratma" ifadeleri benimsenmiş; "Değerlendirme" ve "Yaratma" basamaklarının da sınıflandırmadaki sıraları değiştirilmiştir. Buna göre sınıflandırma tablosunun temel bilişsel süreç basamakları ve bu süreçleri içeren örnekler şöyle gösterilebilir:

"Hatırlama: İlgili bilgiyi uzun süreli bellekten geri getirme (Örnek: Dünya tarihindeki önemli olayların tarihini tanıma).

Anlama: Öğretimsel mesajdan sözel, yazılı ya da grafiksel bir iletişim olarak anlam oluşturma (Örnek: Çeşitli sanatsal resimlere örnekler verme).

Uygulama: Verilen bir durumda işlemi uygulama ya da kullanma (Örnek: Çok basamaklı bir tamsayıyı bir başka tamsayıya bölme).

Çözümleme: Materyali bileşenlerine ayırma ve parçaların birbiriyle / bütünle nasıl bir ilişki içinde olduğunu tespit etme (Örnek: Bir matematik problemindeki ilgili ve ilgisiz sayıları ayırt etme).

Değerlendirme: Ölçütlere ve standartlara dayalı yargıya varma (Örnek: Bir bilim insanının gözlenmiş verilerle bilimsel bir sonuç çıarıp çıkarmadığını belirleme).

Yaratma: Ö̆ğeleri tutarlı ya da işlevsel bir yapıda bir araya getirme, öğeleri yeni bir örüntü ya da yapı içerisinde yeniden düzenleme (Örnek: Verilen tarihsel bir konuda araştırma planı tasarlama) (Anderson \& Krathwohl, 2001; akt. Bümen, 2006: 6).”

Alanyazın incelendiğinde ders kitaplarının Bloom Sınıflandırması'na göre ele alındı̆̆ı (Kuzu, 2013; Eroğlu ve Kuzu, 2014; Tosunoğlu ve Demir, 2014; Oktay, 2015; Tüm, 2016; Durukan ve Demir, 2017; Küçükaydın ve İşcan, 2017; Biçer, 2019; Eroğlu, 2019; Ulutaş ve Kara, 2019; Kana ve Güney, 2020; Kurt, 2020; Sallabaş ve Yılmaz, 2020; Yıldırım, 2020; Kaplan, 2021; Oryaşın, 2021) birçok çalışma

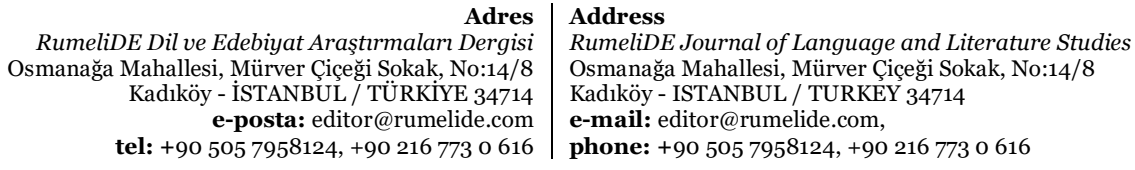


saptanmıştır. Fakat Kuzey Kıbrıs Türk Cumhuriyeti Türkçe ders kitaplarının Bloom Sinıflandırması'na göre incelendiği herhangi bir çalışmaya rastlanmamıştır. Çalışmanın bu yönüyle alana katkı sağlayacağı düşünülmektedir.

$\mathrm{Bu}$ çalışmanın amacı, KKTC Türkçe ders kitaplarındaki etkinliklerin Yenilenmiş Bloom Sınıflandırması'na göre incelenmesidir. Bu amaç doğrultusunda "KKTC 6. sınıf Türkçe ders kitabındaki okuma metinlerine yönelik hazırlanan etkinlikler Yenilenmiş Bloom Sınıflandırması'na göre nasıl bir dağılım göstermektedir?” sorusuna yanıt aranmıştır.

\section{Yöntem}

$\mathrm{Bu}$ araştırma nitel araştırma yöntemlerinden doküman incelemesi kullanılarak yapılmıştır. Creswell (2005) dokümanların nitel araştırmalarda önemli birer veri kaynağı olduğunu ve hem özel hem de resmi dokümanların bu kapsamda ele alınabileceğini belirtir. Bu çalışmada da incelenen doküman araştırmanın amacına uygun olarak KKTC 6. sınıf Türkçe ders kitabındaki okuma metinlerine yönelik hazırlanan etkinliklerdir.

\section{Çalışma materyali}

Araştırmanın çalışma materyalini KKTC Milli Eğitim ve Kültür Bakanlığı tarafından 2018 yılında yayımlanan "Türkçe 6. Sınıf 1. Kitap" oluşturmaktadır. KKTC Türkçe dersleri, her sınıf düzeyinde 2 ayrı kitaptan oluşmaktadır. Bu çalışmada da Türkçe 6. Sınıf 1. Kitap’taki okuma metinlerinde yer alan etkinlikler değerlendirilmiştir. İlgili kitap 3 tema ve her temada yer alan 5 okuma metninden oluşmaktadır. Dolayısıyla kitapta 15 okuma metni yer almaktadır. Bunun yanı sıra her temanın sonunda serbest okuma metni de bulunmaktadır.

İlgili ders kitabı ve bu kitapta yer alan metin sayıları ile ilgili bilgiler aşağıdaki tabloda yer almaktadır:

Tablo 2. İlgili ders kitabı ve bu kitapta yer alan metin sayıları

\begin{tabular}{llllll}
\hline Adı & Yayınevi & Basım Yılı & Yazar/lar & Tema Sayısı & Metin Sayısı \\
\hline Türkçe 6 & KKTC Milli & 2018 & Fatma Ö. Vurana & \\
1. Kitap & Eğitim ve Kültür & & Özge Eliz Aksaygın \\
& Bakanlı̆̆ı & Ayşe Atasayan Uluöz & & 15 \\
& & İem Özakıncı & \\
\hline
\end{tabular}

\section{Verilerin toplanması}

Araştırmada veriler, nitel araştırma yöntemlerinden doküman incelemesine göre toplanmıştır. Yıldırım ve Şimşek (2008) nitel araştırmayı "gözlem, görüşme ve doküman analizi gibi nitel veri toplama yöntemlerinin kullanıldığı, algıların ve olayların doğal ortamda gerçekçi ve bütüncül bir biçimde ortaya konmasına yönelik nitel bir sürecin izlendiği araştırma" olarak tanımlamaktadırlar. Miles ve Huberman (2015) nitel verinin "iyi yapılandırılmış, zengin tanımlamalara ve sürece ilişkin ayrıntılı açıklamalara dayandığını" belirtmektedir.

Doküman incelemesi ise araştırılması amaçlanan olgular ile ilgili bilgileri kapsayan yazılı ürünlerin analizine dayanır (Ylldırım ve Şimşek, 2008). Belgesel gözlem veya belgesel tarama olarak da adlandırılmaktadır (Çepni, 2012). Belgesel tarama, belli bir hedef için kaynakları toplama, okuma, not alma ve değerlendirme süreçlerini içerir (Karasar, 2007). Bu analiz türünde araştırmacı/lar ilk olarak

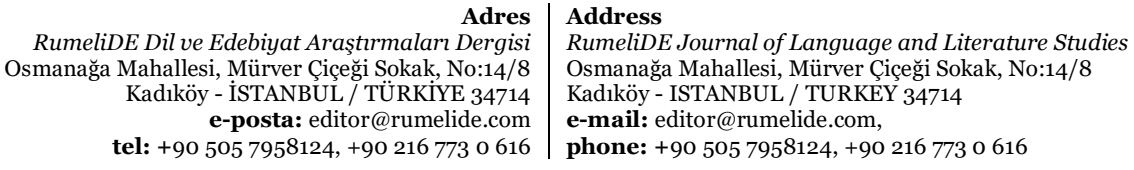


amacına uygun kaynakları toplar, dikkatli şekilde okur, ihtiyaç duyulan bilgileri not eder ve o notlar doğrultusunda değerlendirmeler yapar (Çepni, 2012).

Çalışmada kuramsal kısmın yapısını ortaya koymak için ilk olarak alanyazın taraması yapılmış, araştırma konusuna uyan tez, makale ve diğer bilimsel çalışmalar detaylı bir şekilde ele alınmış ve gerekli notlar çıkarılmıştır. Son olarak KKTC 6. sınıf Türkçe ders kitabındaki okuma metinlerine yönelik hazırlanan etkinlikler incelenmiştir.

\section{Verilerin analizi ve yorumlanması}

Çalışmada toplanan veriler betimsel analiz tekniğiyle çözümlenmiştir. "Betimsel analiz içerik analizine göre daha yüzeysel bir analiz yöntemidir. Bu analizde elde edilen veriler, önceden belirlenmiş başlıklar altında özetlenir ve yorumlanır. Amaç, elde edilen bulguları, düzenlenmiş ve yorumlanmış bir biçimde okuyucuya sunmaktır” (Ylldırım ve Şimşek, 2008).

Çalışmada veriler toplandıktan sonra çalışma için betimsel analize uygun bir çerçeve oluşturulmuş, alanyazın taranmış, benzer çalışmalara bakılmıştır. Çalışmada gerekli yerlerde 2 Türkçe eğitimi uzmanının görüşüne başvurulmuştur.

\section{Bulgular}

Çalışmanın bu bölümünde ulaşılan bulgular, tema ve metinler bağlamında ele alınmıştır.

\section{1. tema: ben ve çevrem}

KKTC 6. sınıf Türkçe ders kitabının birinci teması olan "Ben ve Çevrem" temasında beş okuma metnine yer verilmiştir. Bunlar "Zengin Adam”, "Oduncunun Kızı” , "Bebeklerin Ulusu Yok” , "İçimizdeki Güzellikler" ve "Sokak" metinleridir. Bu metinlerde yer alan etkinliklerin Yenilenmiş Bloom Sinıflandırması'na göre incelenmesi aşağıda verilmiştir.

Tablo 3. "Zengin Adam” metni etkinliklerinin Yenilenmiş Bloom Sınıflandırması’na göre dağılımı

\begin{tabular}{|c|c|c|c|c|c|c|c|}
\hline & $\begin{array}{l}\text { Etkinlik } \\
\text { No }\end{array}$ & Hatırlama & Anlama & Uygulama & Çözümleme & Değerlendirme & Yaratma \\
\hline \multirow{4}{*}{ 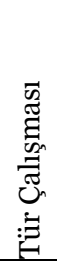 } & 1 & & & & & & $\checkmark$ \\
\hline & 2 & & $\checkmark$ & & & & \\
\hline & 3 & & $\sqrt{ }$ & $\sqrt{ }$ & & & \\
\hline & 4 & & $\sqrt{ }$ & & & & \\
\hline \multirow{3}{*}{ 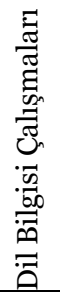 } & 1 & $\checkmark$ & & & & & \\
\hline & 2 & $\checkmark$ & & & & & \\
\hline & 3 & $\checkmark$ & $\checkmark$ & & & & \\
\hline
\end{tabular}

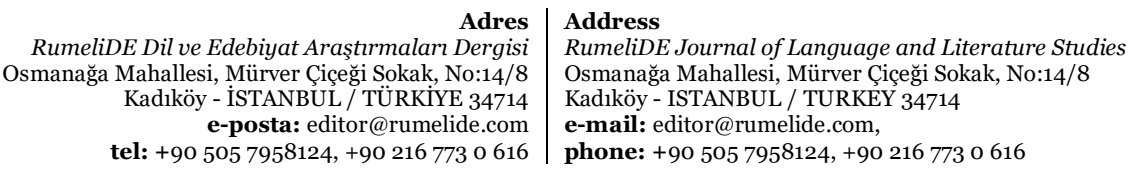


Tablo 3 incelendiğinde "Zengin Adam" okuma metninde 8 etkinliğin yer aldığı ve bu etkinliklerde anlama basamağına 4, hatırlama basamağına 3, uygulama ve yaratma basamaklarına ise 1'er etkinlikte yer verildiği; çözümleme ve değerlendirme basamaklarına ise etkinliklerde yer verilmediği görülmektedir. Bu metinde yer alan ve yaratma basamağına uygun olduğu düşünülen bir etkinlik örneği aşağıda verilmiştir.

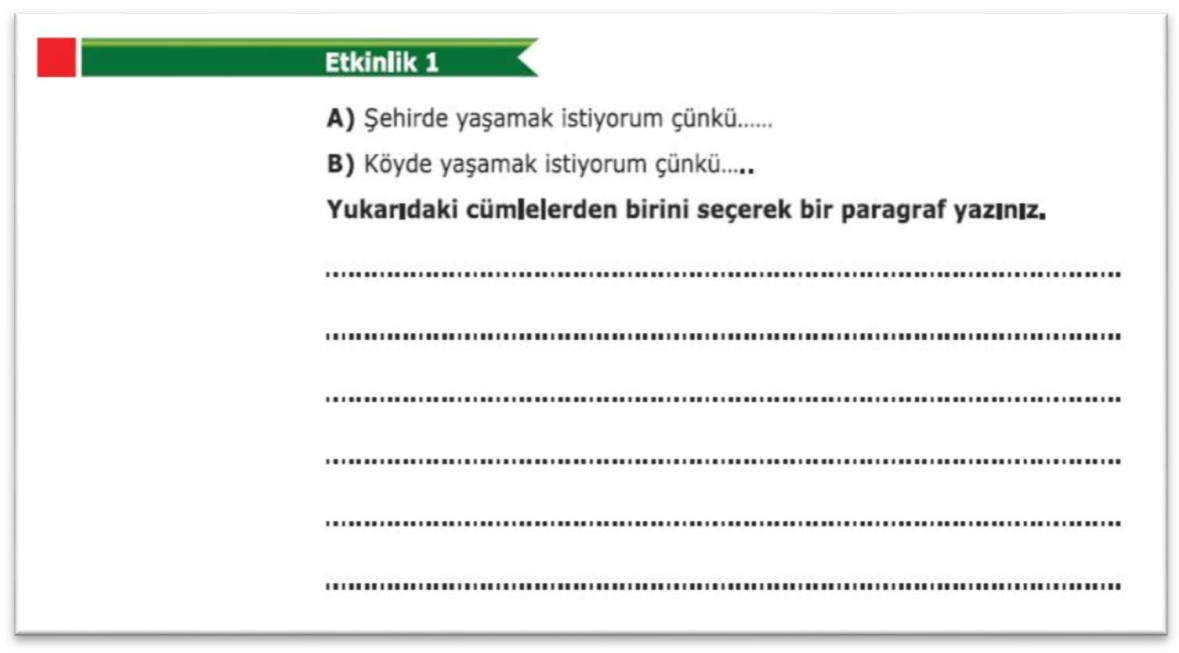

Tablo 4. "Oduncunun Kızı” metni etkinliklerinin Yenilenmiş Bloom Sınıflandırması’na göre dă̆ılımı

\begin{tabular}{|c|c|c|c|c|c|c|c|}
\hline & $\begin{array}{l}\text { Etkinlik } \\
\text { No }\end{array}$ & Hatırlama & Anlama & Uygulama & Çözümleme & Değerlendirme & Yaratma \\
\hline \multirow{6}{*}{ 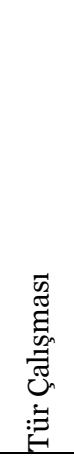 } & 1 & & & $\sqrt{ }$ & & & \\
\hline & 2 & $\checkmark$ & $\sqrt{ }$ & & & & \\
\hline & 3 & & $\sqrt{ }$ & & & & \\
\hline & 4 & & $\sqrt{ }$ & & & & \\
\hline & 5 & $\sqrt{ }$ & $\sqrt{ }$ & & & & \\
\hline & 6 & & $\sqrt{ }$ & & & & $\sqrt{ }$ \\
\hline & 1 & & $\sqrt{ }$ & & & & \\
\hline 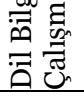 & 2 & & $\sqrt{ }$ & & & & \\
\hline
\end{tabular}

Tablo 4 incelendiğinde "Oduncunun Kızı" okuma metninde 8 etkinliğin yer aldığı ve bu etkinliklerde anlama basamağına 7 , hatırlama basamağına 2, uygulama ve yaratma basamaklarına ise 1'er etkinlikte yer verildiği; çözümleme ve değerlendirme basamaklarına ise etkinliklerde yer verilmediği görülmektedir. Bu metinde yer alan ve uygulama basamağına uygun olduğu düşünülen bir etkinlik örneği aşağıda verilmiştir.

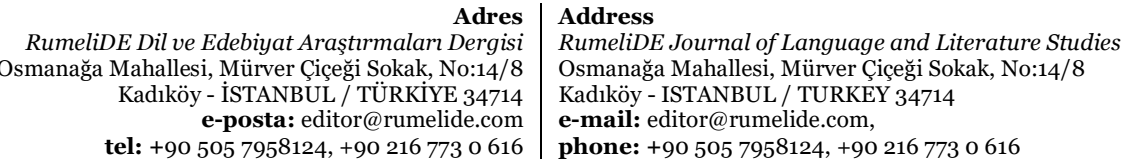




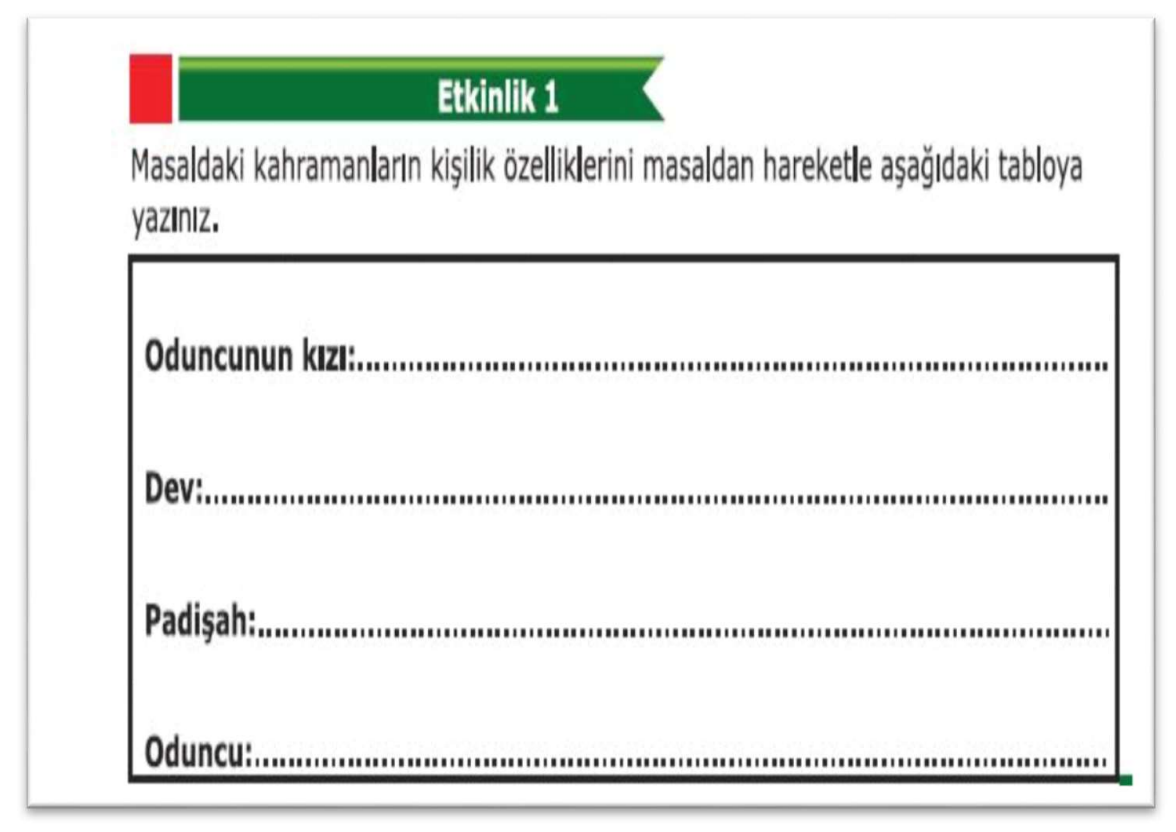

Tablo 5. "Bebeklerin Ulusu Yok" metni etkinliklerinin Yenilenmiş Bloom Sınıflandırması’na göre dağılımı

\begin{tabular}{|c|c|c|c|c|c|c|c|}
\hline & $\begin{array}{l}\text { Etkinlik } \\
\text { No }\end{array}$ & Hatırlama & Anlama & Uygulama & Çözümleme & Değerlendirme & Yaratma \\
\hline \multirow{2}{*}{ 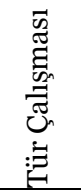 } & 1 & $\sqrt{ }$ & & & & & \\
\hline & 2 & & & & & & $\sqrt{ }$ \\
\hline \multirow{2}{*}{ 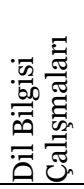 } & 1 & & $\sqrt{ }$ & & & & \\
\hline & 2 & $\sqrt{ }$ & & $\sqrt{ }$ & & & \\
\hline
\end{tabular}

Tablo 5 incelendiğinde "Bebeklerin Ulusu Yok" okuma metninde 4 etkinliğin yer aldığ ve bu etkinliklerde hatırlama basamağına 2, anlama, uygulama ve yaratma basamaklarına ise 1'er etkinlikte yer verildiği; uygulama, çözümleme ve değerlendirme basamaklarına ise etkinliklerde yer verilmediği görülmektedir. Bu metinde yer alan ve hatırlama, uygulama basamaklarına uygun olduğu düşünülen bir etkinlik örneği aşağıda verilmiştir.

Adres

RumeliDE Dil ve Edebiyat Araşturmaları Dergisi Osmanağa Mahallesi, Mürver Çiçeği Sokak, No:14/8 Kadıköy - ÍSTANBUL / TÜRKIYE 34714 e-posta: editor@rumelide.com tel: +90 $5057958124,+902167730616$
Address

RumeliDE Journal of Language and Literature Studies Osmanağa Mahallesi, Mürver Çiçeği Sokak, No:14/8

Kadıköy - ISTANBUL / TURKEY 34714

e-mail: editor@rumelide.com,

phone: +90 $5057958124,+902167730616$ 
An examination of activities in TRNC Turkish textbooks according to Bloom's Revised Taxonomy: An example of sixth grade turkish textbook / B. Sarıkaya; Y. Şakiroğlu (pp. 273-296)

\section{Etkinlik 2}

Aşağıdaki sözcükleri hem terim hem de mecaz anlamında birer cümlede kullanınız.

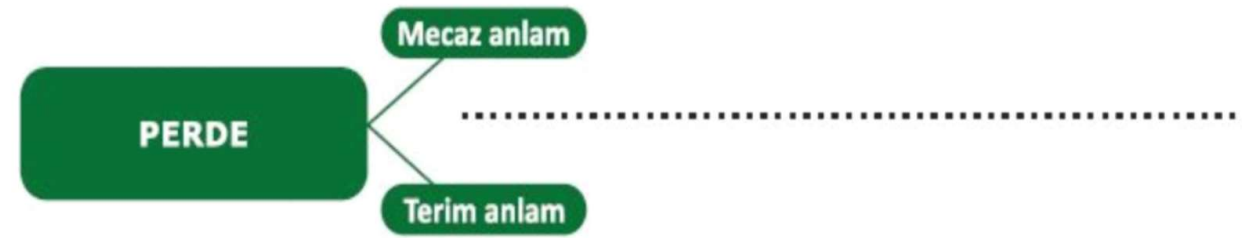

Terim anlam

Mecaz anlam

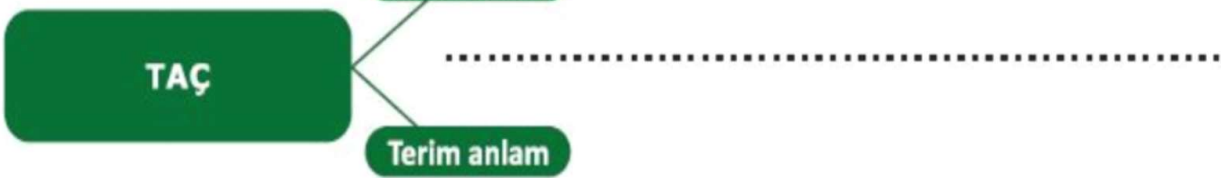

Terim anlam

Mecaz anlam

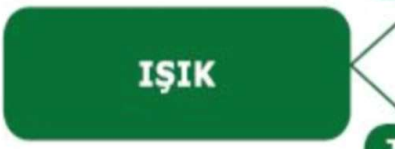

Terim anlam

Tablo 6. "İçimizdeki Güzellikler" metni etkinliklerinin Yenilenmiş Bloom Sınıflandırması’na göre dağılımı

\begin{tabular}{|c|c|c|c|c|c|c|c|}
\hline & $\begin{array}{l}\text { Etkinlik } \\
\text { No }\end{array}$ & Hatırlama & Anlama & Uygulama & Çözümleme & Değerlendirme & Yaratma \\
\hline \multirow{2}{*}{ 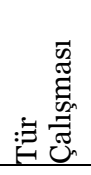 } & 1 & $\sqrt{ }$ & & & & & $\sqrt{ }$ \\
\hline & 2 & $\sqrt{ }$ & & & & $\sqrt{ }$ & $\sqrt{ }$ \\
\hline \multirow{2}{*}{ 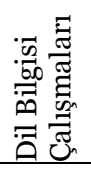 } & 1 & $\sqrt{ }$ & & & & & \\
\hline & 2 & $\sqrt{ }$ & & & & & \\
\hline
\end{tabular}

Tablo 6 incelendiğinde "İçimizdeki Güzellikler" okuma metninde 4 etkinliğin yer aldı̆̆ ve bu etkinliklerde hatırlama basamağına 4, yaratma basamağına 2 ve değerlendirme basamağına 1 etkinlikte yer verildiği; anlama, uygulama ve çözümleme basamaklarına ise etkinliklerde yer verilmediği

\footnotetext{
\begin{tabular}{r|l} 
Adres & Address \\
RumeliDE Dil ve Edebiyat Araştirmaları Dergisi & RumeliDE Journal of Language and Literature Studies
\end{tabular}

Osmanağa Mahallesi, Mürver Çiçeği Sokak, No:14/8 $\quad$ Osmanağa Mahallesi, Mürver Çiçeği Sokak, No:14/8

Kadıköy - ISTANBUL / TÜRKIYE 34714 Kadıköy - ISTANBUL / TURKEY 34714

e-posta: editor@rumelide.com e-mail: editor@rumelide.com,

tel: +90 $5057958124,+902167730616$ phone: +90 505 7958124, +90 2167730616
} 
görülmektedir. Bu metinde yer alan ve yaratma basamağına uygun olduğu düşünülen bir etkinlik örneği aşağıda verilmiştir.

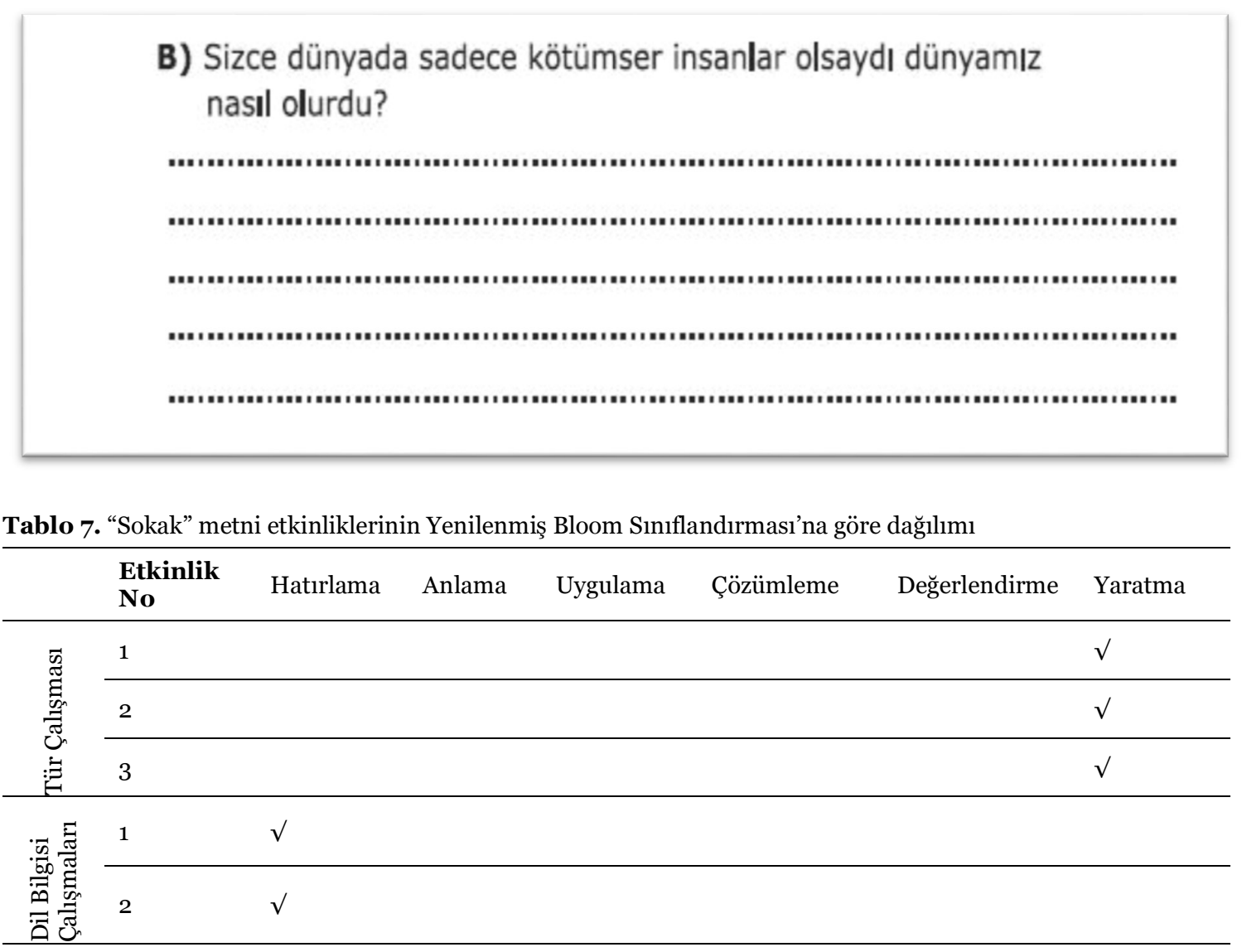

Tablo 7 incelendiğinde "Sokak" okuma metninde 5 etkinliğin yer aldığı ve bu etkinliklerde yaratma basamağına 3 , hatırlama basamağına 2 etkinlikte yer verildiği; anlama, uygulama, çözümleme ve değerlendirme basamaklarına ise etkinliklerde yer verilmediği görülmektedir. Bu metinde yer alan ve yaratma basamağına uygun olduğu düşünülen bir etkinlik örneği aşağıda verilmiştir.

Adres

RumeliDE Dil ve Edebiyat Araştırmaları Dergis Osmanağa Mahallesi, Mürver Çiçeği Sokak, No:14/8 Kadıköy - ÍSTANBUL / TÜRKIYE 34714 e-posta: editor@rumelide.com tel: +90 $5057958124,+902167730616$
Address

RumeliDE Journal of Language and Literature Studies Osmanağa Mahallesi, Mürver Çiçeği Sokak, No:14/8

Kadıköy - ISTANBUL / TURKEY 34714

e-mail: editor@rumelide.com,

phone: +90 $5057958124,+902167730616$ 


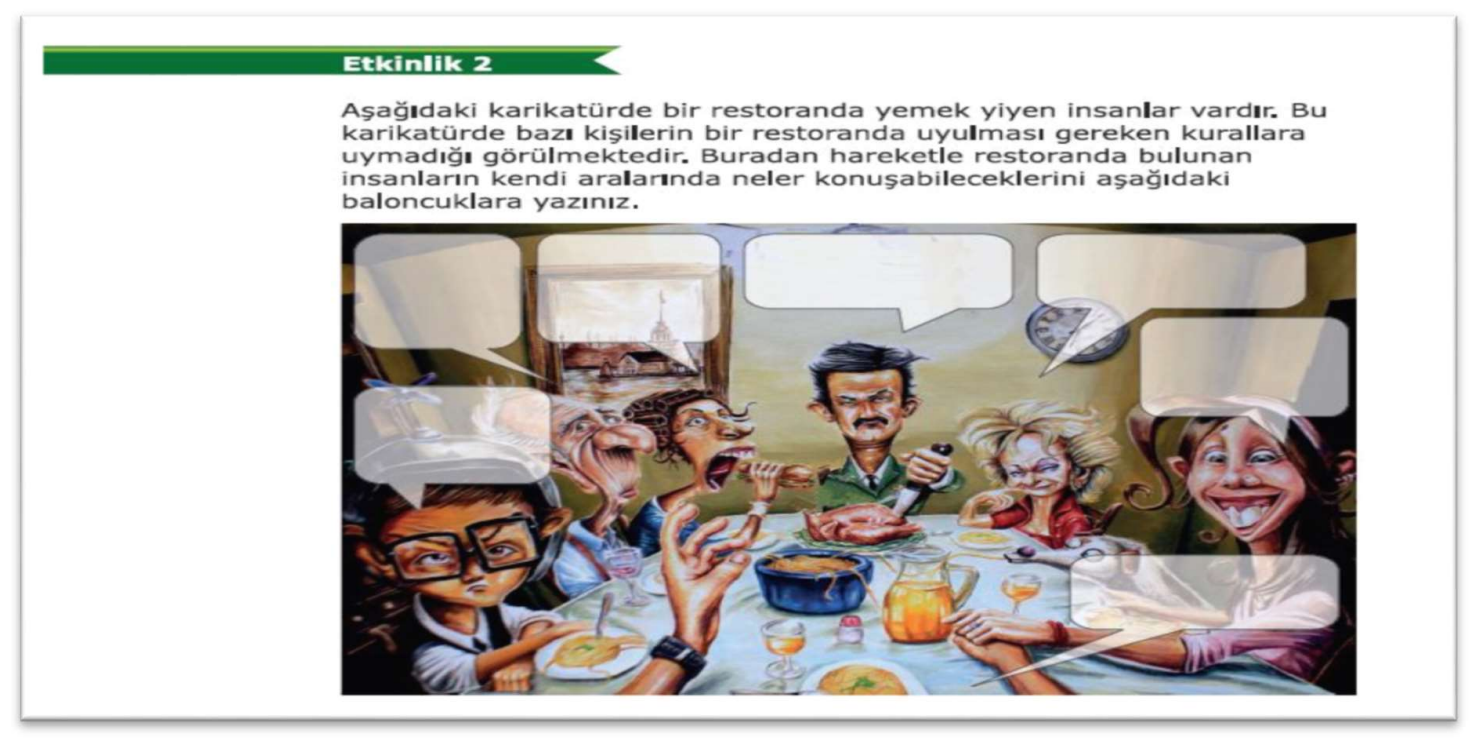

\section{2. tema: ülkem ve kültürel değerlerim}

KKTC 6. sınıf Türkçe ders kitabının ikinci teması olan "Ülkem ve Kültürel Değerlerim” temasında beş okuma metnine yer verilmiştir. Bunlar "Atatürk’ten Anılar” , “Atatürk” , “Afrodit Memleketi Kıbrıs 'Karpaz”, , "Başarıya Giden Yol” ve "Kaplumbağalar” metinleridir. Bu metinlerde yer alan etkinliklerin Yenilenmiş Bloom Sınıflandırması’na göre incelenmesi aşağıda verilmiştir.

Tablo 8. “Atatürk’ten Anılar” metni etkinliklerinin Yenilenmiş Bloom Sınıflandırması’na göre dağılımı

\begin{tabular}{|c|c|c|c|c|c|c|c|}
\hline & $\begin{array}{l}\text { Etkinlik } \\
\text { No }\end{array}$ & Hatırlama & Anlama & Uygulama & Çözümleme & Değerlendirme & Yaratma \\
\hline \multirow{4}{*}{ 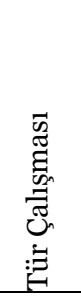 } & 1 & $\sqrt{ }$ & & & & & $\sqrt{ }$ \\
\hline & 2 & $\sqrt{ }$ & & $\sqrt{ }$ & & & \\
\hline & 3 & & & $\sqrt{ }$ & & & \\
\hline & 4 & $\checkmark$ & & & & & \\
\hline \multirow{2}{*}{ 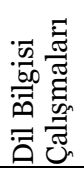 } & 1 & $\sqrt{ }$ & & & & & \\
\hline & 2 & & $\sqrt{ }$ & & & & \\
\hline
\end{tabular}

Tablo 8 incelendiğinde “Atatürk’ten Anılar” okuma metninde 6 etkinliğin yer aldığı ve bu etkinliklerde hatırlama basamağına 4, uygulama basamağına 2, anlama ve yaratma basamaklarına 1'er etkinlikte yer verildiği; çözümleme ve değerlendirme basamaklarına ise etkinliklerde yer verilmediği görülmektedir. $\mathrm{Bu}$ metinde yer alan ve uygulama basamağına uygun olduğu düşünülen bir etkinlik örneği aşağıda verilmiştir.

RumeliDE Dil ve Edebiyat Arasturmalari Osmană̆a Mahallesi, Mürver Ciç̧⿻̆丶i Sokak, No:14/8 Kadıköy - ÍSTANBUL / TÜRKIYE 34714 e-posta: editor@rumelide.com tel: $+905057958124,+902167730616$
Address

RumeliDE Journal of Language and Literature Studies Osmanağa Mahallesi, Mürver Çiçeği Sokak, No:14/8

Kadıköy - ISTANBUL / TURKEY 34714

e-mail: editor@rumelide.com

phone: +90 505 7958124, +90 2167730616 
b) Atatürk'ün devrimleri ile ilgili bir anı bulup aşağıda boş bırakılan yere yazınız ve bu anıda Atatürk'ün hangi özelliklerinin yansıtıldığını belirtiniz.

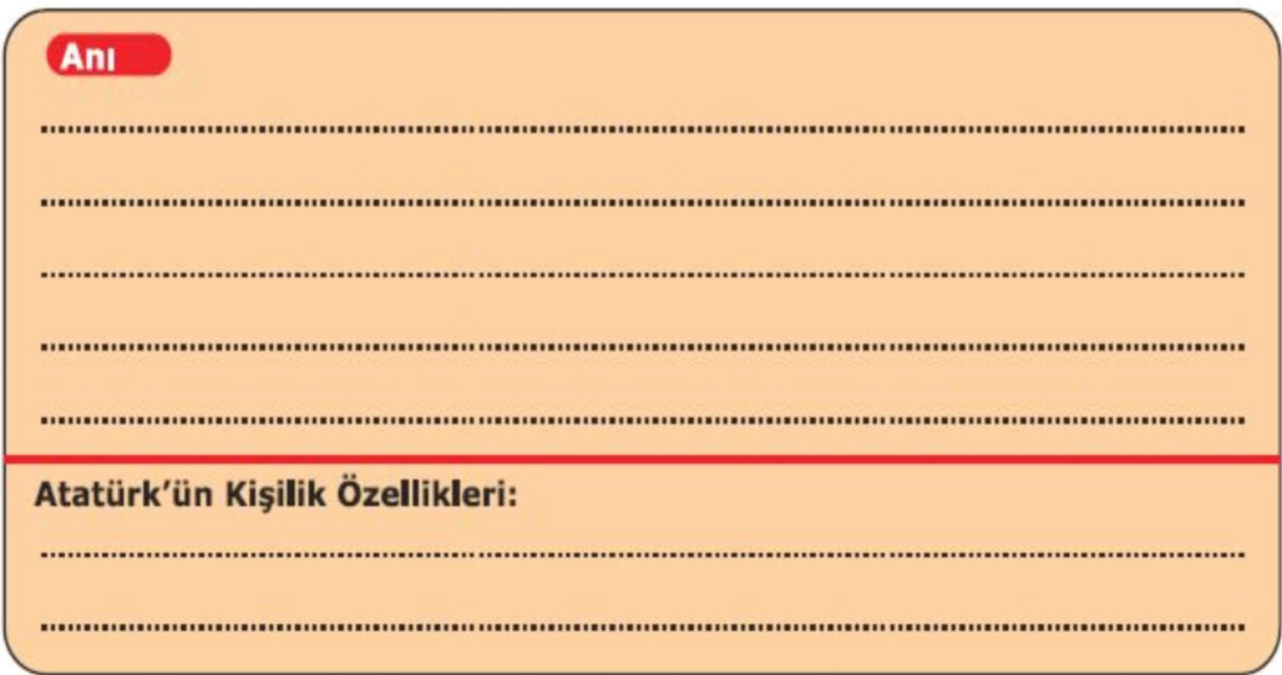

Tablo 9. "Atatürk" metni etkinliklerinin Yenilenmiş Bloom Sınıflandırması’na göre dağıllımı

\begin{tabular}{|c|c|c|c|c|c|c|c|}
\hline & $\begin{array}{l}\text { Etkinlik } \\
\text { No }\end{array}$ & Hatırlama & Anlama & Uygulama & Çözümleme & Değerlendirme & Yaratma \\
\hline \multirow{4}{*}{ 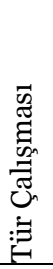 } & 1 & $\sqrt{ }$ & & & & & \\
\hline & 2 & & & & & & $\checkmark$ \\
\hline & 3 & & & $\sqrt{ }$ & & & \\
\hline & 4 & $\sqrt{ }$ & & & & & \\
\hline \multirow{3}{*}{ 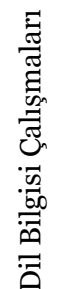 } & 1 & $\sqrt{ }$ & & & & & \\
\hline & 2 & $\sqrt{ }$ & & & & & \\
\hline & 3 & & & $\sqrt{ }$ & & & \\
\hline
\end{tabular}

Tablo 9 incelendiğinde "Atatürk" okuma metninde 7 etkinliğin yer aldığı ve bu etkinliklerde hatırlama basamağına 4, uygulama basamağına 2, yaratma basamağına 1 etkinlikte yer verildiği; anlama, çözümleme ve değerlendirme basamaklarına ise etkinliklerde yer verilmediği görülmektedir. $\mathrm{Bu}$ metinde yer alan ve yaratma basamağına uygun olduğu düşünülen bir etkinlik örneği aşağıda verilmiştir. 
An examination of activities in TRNC Turkish textbooks according to Bloom's Revised Taxonomy: An example of sixth grade turkish textbook / B. Sarıkaya; Y. Şakiroğlu (pp. 273-296)

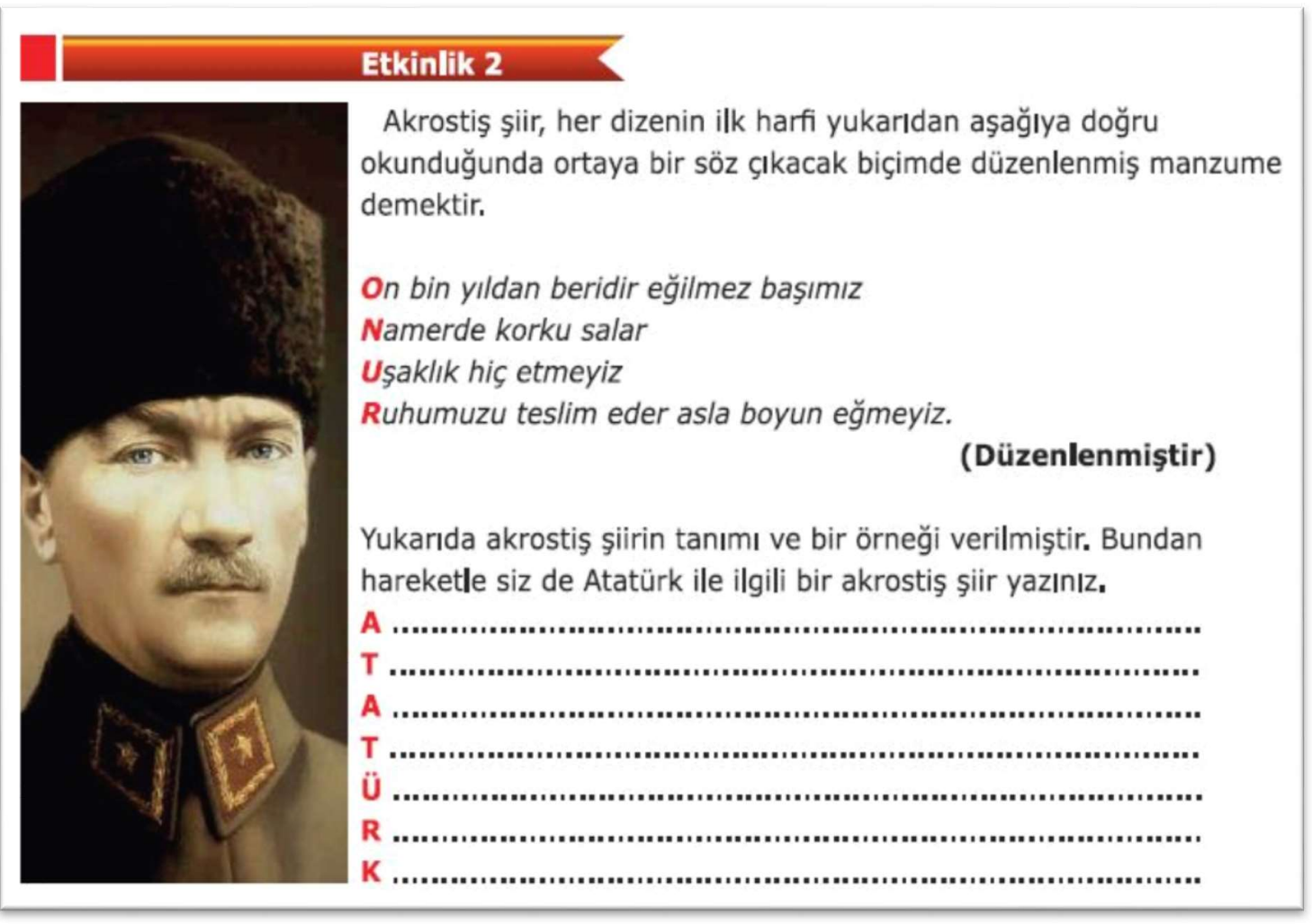

Tablo 10. “Afrodit Memleketi Kıbrıs ‘Karpaz” metni etkinliklerinin Yenilenmiş Bloom Sınıflandırması’na göre dağılımı

\begin{tabular}{|c|c|c|c|c|c|c|c|}
\hline & $\begin{array}{l}\text { Etkinlik } \\
\text { No }\end{array}$ & Hatırlama & Anlama & Uygulama & Çözümleme & Değerlendirme & Yaratma \\
\hline \multirow{4}{*}{ 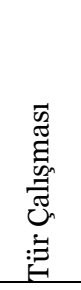 } & 1 & $\sqrt{ }$ & & & & & \\
\hline & 2 & $\sqrt{ }$ & & & & & \\
\hline & 3 & $\checkmark$ & & & & & \\
\hline & 4 & $\sqrt{ }$ & & & & & \\
\hline \multirow{2}{*}{ 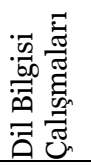 } & 1 & $\sqrt{ }$ & & & & & \\
\hline & 2 & $\sqrt{ }$ & & & & & \\
\hline
\end{tabular}

Tablo 10 incelendiğinde "Afrodit Memleketi Kıbrıs ‘Karpaz”" okuma metninde 6 etkinliğin yer aldığı ve bu etkinliklerin tamamında hatırlama basamağına yer verildiği; metinde yer alan etkinliklerin hiçbirinde diğer basamaklara yer verilmediği göze çarpmaktadır. Bu metinde yer alan ve hatırlama basamağına uygun olduğu düşünülen bir etkinlik örneği aşağıda verilmiştir.

RumeliDE Dil ve Edebiyat Arasturmalar Adres Osmanağa Mahallesi, Mürver Ciç̧̌̆i Sokak, No:14/8 Kadıköy - ISTANBUL / TÜRKIYE 34714 e-posta: editor@rumelide.com tel: $+905057958124,+902167730616$
Address

RumeliDE Journal of Language and Literature Studies

Osmanağa Mahallesi, Mürver Çiçeği Sokak, No:14/8

Kadıköy - ISTANBUL / TURKEY 34714

e-mail: editor@rumelide.com,

phone: +90 505 7958124, +90 2167730616 


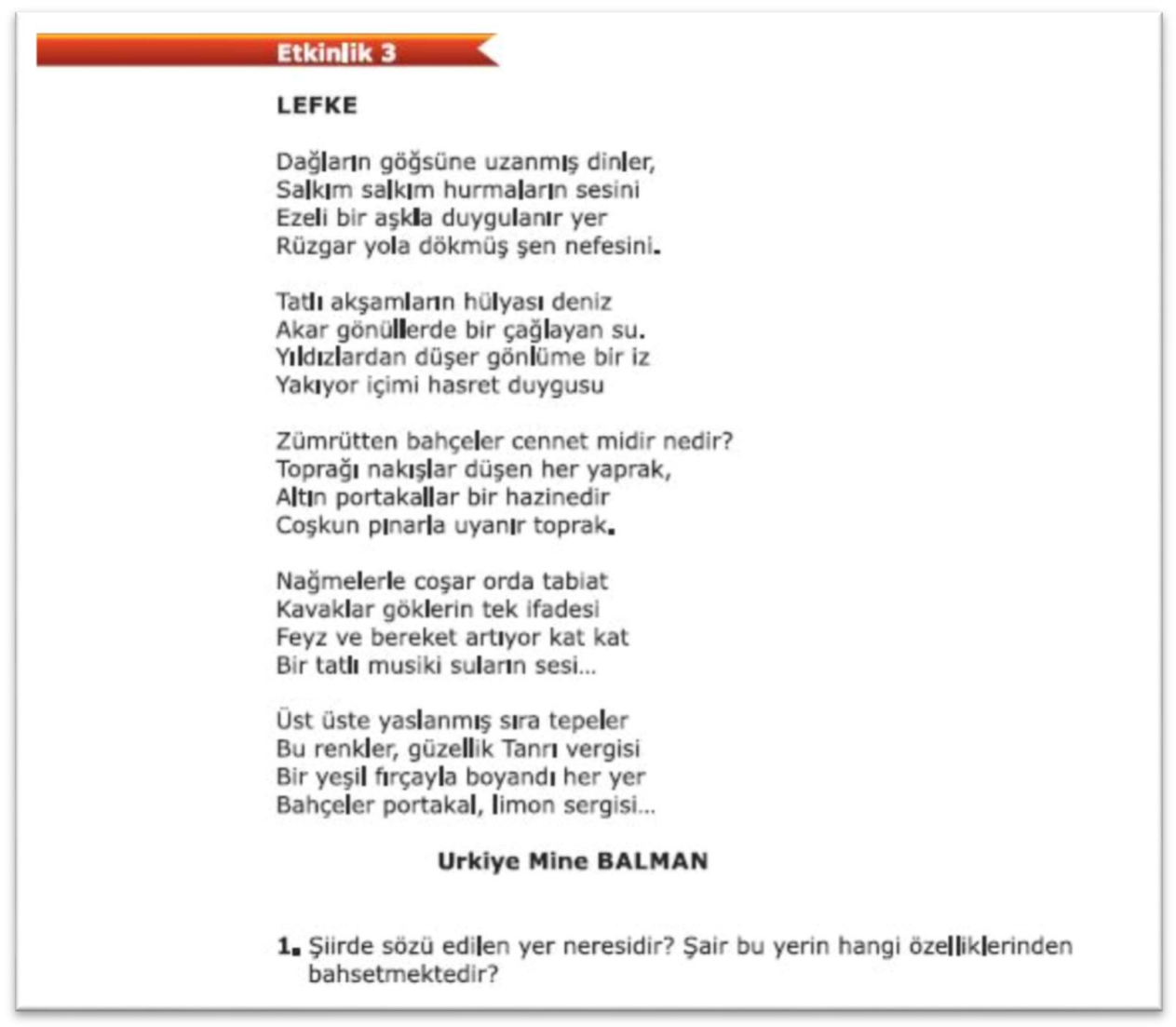

Tablo 11. "Başarıya Giden Yol” metni etkinliklerinin Yenilenmiş Bloom Sinıflandırması’na göre dağılımı

\begin{tabular}{|c|c|c|c|c|c|c|c|}
\hline & $\begin{array}{l}\text { Etkinlik } \\
\text { No }\end{array}$ & Hatırlama & Anlama & Uygulama & Çözümleme & Değerlendirme & Yaratma \\
\hline \multirow{3}{*}{ 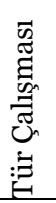 } & 1 & & $\sqrt{ }$ & & & & \\
\hline & 2 & $\sqrt{ }$ & & & & & \\
\hline & 3 & & & $\sqrt{ }$ & & & \\
\hline \multirow{3}{*}{ 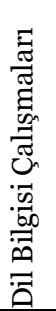 } & 1 & $\sqrt{ }$ & & & & & \\
\hline & 2 & $\sqrt{ }$ & & $\sqrt{ }$ & & & \\
\hline & 3 & $\sqrt{ }$ & & $\sqrt{ }$ & & & \\
\hline
\end{tabular}

Tablo 11 incelendiğinde "Başarıya Giden Yol” okuma metninde 6 etkinliğin yer aldığı ve bu etkinliklerde hatırlama basamağına 4, uygulama basamağına 3, anlama basamağına 1 etkinlikte yer verildiği; anlama, çözümleme ve değerlendirme basamaklarına ise etkinliklerde yer verilmediği görülmektedir. $\mathrm{Bu}$ metinde yer alan ve hatırlama basamağına uygun olduğu düşünülen bir etkinlik örneği aşağıda verilmiştir.

Adres | Address

RumeliDE Dil ve Edebiyat Araşturmaları Dergisi $\quad$ RumeliDE Journal of Language and Literature Studies Osmanağa Mahallesi, Mürver Çiçeği Sokak, No:14/8 $\quad$ Osmanağa Mahallesi, Mürver Çiçeği Sokak, No:14/8 Kadıköy - ÍSTANBUL / TÜRKIYE 34714 Kadıköy - ISTANBUL / TURKEY 34714 e-posta: editor@rumelide.com e-mail: editor@rumelide.com, tel: +90 505 7958124, +90 2167730616 phone: +90 505 7958124, +90 2167730616 
An examination of activities in TRNC Turkish textbooks according to Bloom's Revised Taxonomy: An example of sixth grade turkish textbook / B. Sarıkaya; Y. Şakiroğlu (pp. 273-296)

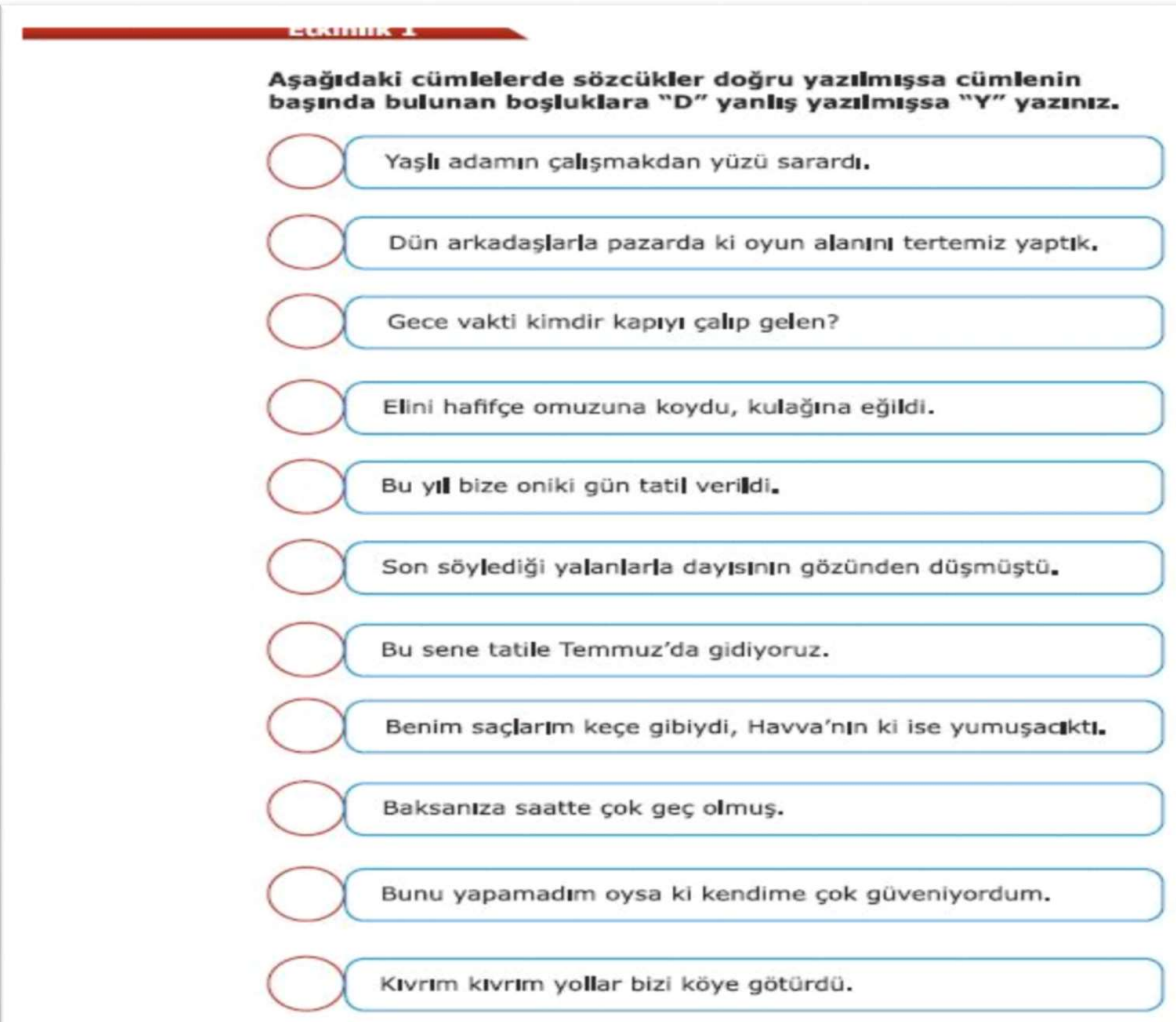

Tablo 12. "Kaplumbağalar” metni etkinliklerinin Yenilenmiş Bloom Sınıflandırması’na göre dağılımı

\begin{tabular}{|c|c|c|c|c|c|c|c|}
\hline & $\begin{array}{l}\text { Etkinlik } \\
\text { No }\end{array}$ & Hatırlama & Anlama & Uygulama & Çözümleme & Değerlendirme & Yaratma \\
\hline \multirow{4}{*}{ 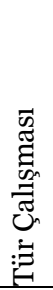 } & 1 & $\sqrt{ }$ & & & & & \\
\hline & 2 & $\sqrt{ }$ & & & & & \\
\hline & 3 & $\sqrt{ }$ & $\sqrt{ }$ & & & & \\
\hline & 4 & & $\sqrt{ }$ & & & & $\sqrt{ }$ \\
\hline \multirow{4}{*}{ 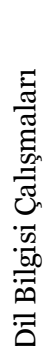 } & 1 & $\sqrt{ }$ & & $\sqrt{ }$ & & & \\
\hline & 2 & $\sqrt{ }$ & & & & & \\
\hline & 3 & $\sqrt{ }$ & & & & & \\
\hline & 4 & $\sqrt{ }$ & $\sqrt{ }$ & & & & \\
\hline
\end{tabular}

Tablo 12 incelendiğinde "Kaplumbağalar" okuma metninde 8 etkinliğin yer aldığı ve bu etkinliklerde hatırlama basamağına 7, anlama basamağına 3, uygulama ve yaratma basamaklarına 1'eretkinlikte yer verildiği; çözümleme ve değerlendirme basamaklarına ise etkinliklerde yer verilmediği görülmektedir.

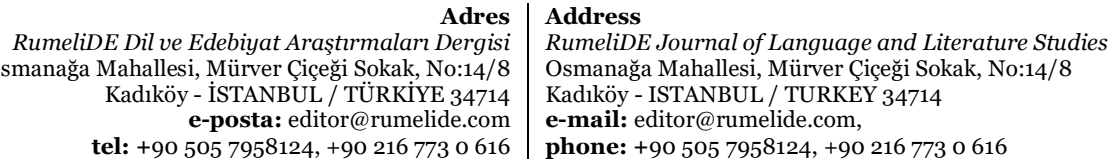


$\mathrm{Bu}$ metinde yer alan ve yaratma basamağına uygun olduğu düşünülen bir etkinlik örneği aşă̆ıda verilmiştir.

\section{Okuduğunuz metnin sonu verilmemiştir. Metni kendinize göre tamamlayınız.}

"

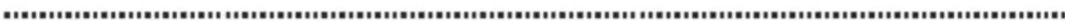

\section{3. tema: duygularim}

KKTC 6. sınıf Türkçe ders kitabının üçüncü teması olan "Duygularım” temasında beş okuma metnine yer verilmiştir. Bunlar "Lise Defteri”, "Suda Kendini Gören Geyik”, “İhtiyar Balıkçı”, "Dost Bildiklerim” ve "Güler Yüz" metinleridir. Bu metinlerde yer alan etkinliklerin Yenilenmiş Bloom Sınıflandırması'na göre incelenmesi aşağıda verilmiştir.

Tablo 13. "Lise Defteri” metni etkinliklerinin Yenilenmiş Bloom Sınıflandırması’na göre dağılımı

\begin{tabular}{|c|c|c|c|c|c|c|c|}
\hline & $\begin{array}{l}\text { Etkinlik } \\
\text { No }\end{array}$ & Hatırlama & Anlama & Uygulama & Çözümleme & Değerlendirme & Yaratma \\
\hline \multirow{3}{*}{ 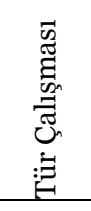 } & 1 & $\sqrt{ }$ & & & & & \\
\hline & 2 & $\sqrt{ }$ & & & & & \\
\hline & 3 & & $\sqrt{ }$ & & & & \\
\hline \multirow{2}{*}{ 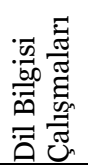 } & 1 & & & $\sqrt{ }$ & & & \\
\hline & 2 & $\sqrt{ }$ & & $\sqrt{ }$ & & & \\
\hline
\end{tabular}

Tablo 13 incelendiğinde "Lise Defteri" okuma metninde 5 etkinliğin yer aldığı ve bu etkinliklerde hatırlama basamağına 3, uygulama basamağına 2, anlama basamağına 1 etkinlikte yer verildiği; çözümleme, değerlendirme ve yaratma basamaklarına ise etkinliklerde yer verilmediği görülmektedir. $\mathrm{Bu}$ metinde yer alan ve hatırlama basamağına uygun olduğu düşünülen bir etkinlik örneği aşağıda verilmiştir. 


\section{Etkin ilk 1}

\section{Aşağıdaki deyimleri anlamlarına göre verilen cümlelerle} eşleştiriniz.

\section{a) Yürekler acısı}

b) Kendini beğenmek

c) Ödü kopmak

d) Göz göze gelmek
Dün okuldan eve dönerken karșıma köpek çıkınca çok korktum.

\section{Savaşta evini yurdunu kaybeden} insanların hali çok üzücüydü.

\section{O gün nhtımda yürürken mavi elbiseli} güzel kızla bakıştık.

Ali çevresindekileri küçümseyen sürekli kendini öven bir çocuktu.

Tablo 14. "Suda Kendini Gören Geyik” metni etkinliklerinin Yenilenmiş Bloom Sınıflandırması'na göre dağılımı

\begin{tabular}{|c|c|c|c|c|c|c|c|}
\hline & $\begin{array}{l}\text { Etkinlik } \\
\text { No }\end{array}$ & Hatırlama & Anlama & Uygulama & Çözümleme & Değerlendirme & Yaratma \\
\hline \multirow{4}{*}{ 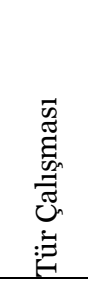 } & 1 & & & $\sqrt{ }$ & & & \\
\hline & 2 & & $\sqrt{ }$ & & & & \\
\hline & 3 & & $\sqrt{ }$ & & & & \\
\hline & 4 & $\sqrt{ }$ & & & & & \\
\hline \multirow{2}{*}{ 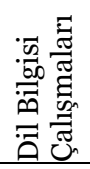 } & 1 & $\sqrt{ }$ & & & & & \\
\hline & 2 & $\sqrt{ }$ & & $\sqrt{ }$ & & & \\
\hline
\end{tabular}

Tablo 14 incelendiğinde "Suda Kendini Gören Geyik" okuma metninde 6 etkinliğin yer aldı̆̆ ve bu etkinliklerde hatırlama basamağına 3, anlama ve uygulama basamaklarına 2'şer etkinlikte yer verildiği; çözümleme, değerlendirme ve yaratma basamaklarına ise etkinliklerde yer verilmediği görülmektedir. $\mathrm{Bu}$ metinde yer alan ve uygulama basamağına uygun olduğu düşünülen bir etkinlik örneği aşağıda verilmiştir.

RumeliDE Dil ve Edebiyat Araşttrmaları Dergisi Osmanağa Mahallesi, Mürver Çiçeği Sokak, No:14/8 Kadıköy - ÍSTANBUL / TÜRKIYE 34714 e-posta: editor@rumelide.com tel: $+905057958124,+902167730616$
Address

RumeliDE Journal of Language and Literature Studies Osmanağa Mahallesi, Mürver Çiçeği Sokak, No:14/ 8

Kadıköy - ISTANBUL / TURKEY 34714

e-mail: editor@rumelide.com,

phone: +90 505 7958124, +90 2167730616 


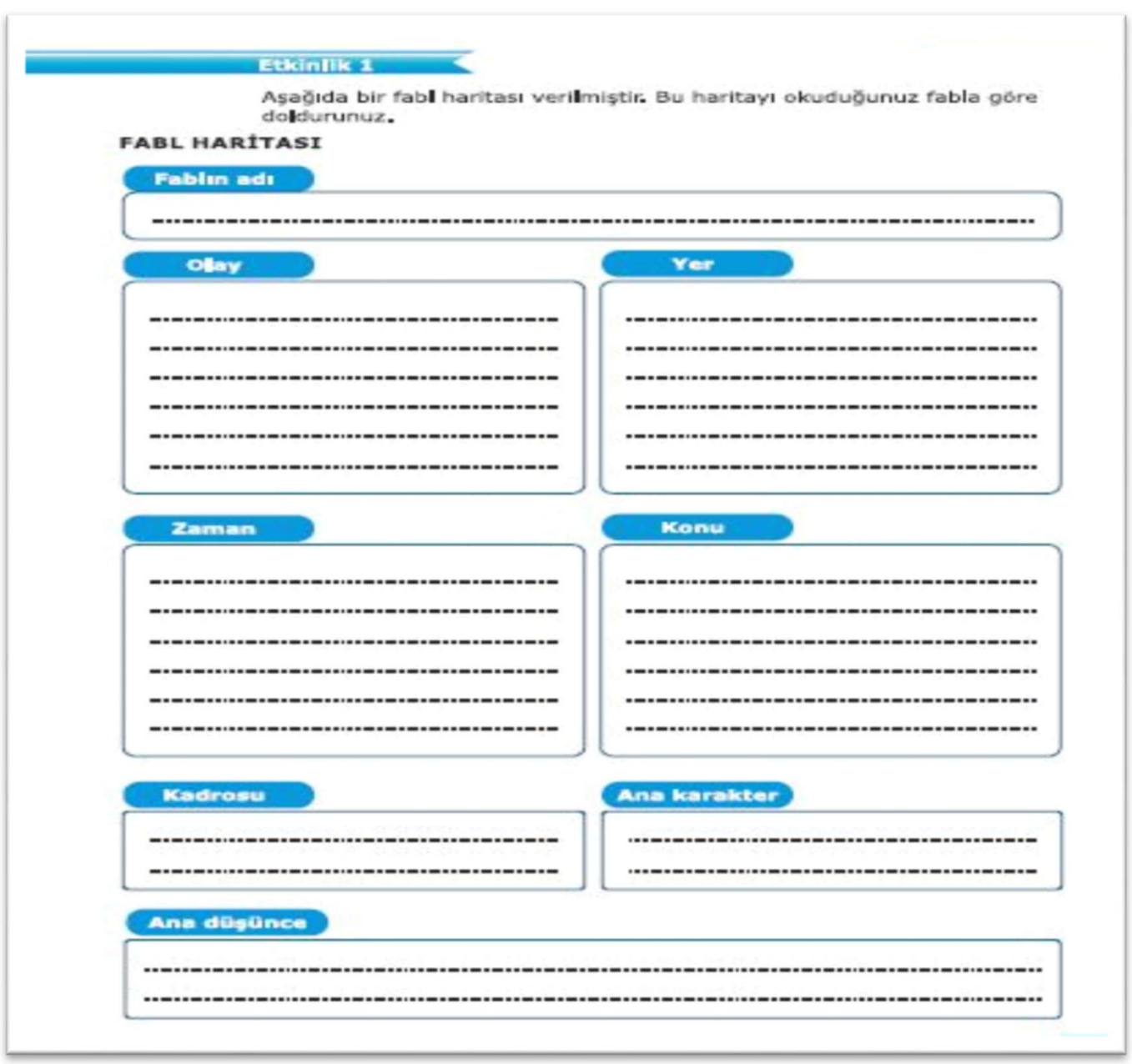

Tablo 15. "İhtiyar Balıkçı" metni etkinliklerinin Yenilenmiş Bloom Sınıflandırması’na göre dağılımı

\begin{tabular}{|c|c|c|c|c|c|c|c|}
\hline & $\begin{array}{l}\text { Etkinlik } \\
\text { No }\end{array}$ & Hatırlama & Anlama & Uygulama & Çözümleme & Değerlendirme & Yaratma \\
\hline \multirow{4}{*}{ 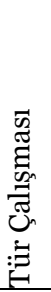 } & 1 & & & $\sqrt{ }$ & & & \\
\hline & 2 & & & $\sqrt{ }$ & & & \\
\hline & 3 & & & & & $\sqrt{ }$ & \\
\hline & 4 & & & & & & $\sqrt{ }$ \\
\hline \multirow{3}{*}{ 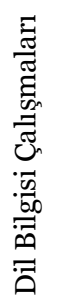 } & 1 & $\sqrt{ }$ & & & & & \\
\hline & 2 & $\sqrt{ }$ & & $\sqrt{ }$ & & & \\
\hline & 3 & $\sqrt{ }$ & & & & & \\
\hline
\end{tabular}


An examination of activities in TRNC Turkish textbooks according to Bloom's Revised Taxonomy: An example of sixth grade turkish textbook / B. Sarıkaya; Y. Şakiroğlu (pp. 273-296)

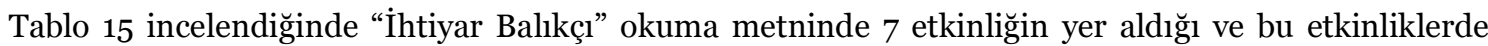
hatırlama ve uygulama basamaklarına 3'er, değerlendirme ve yaratma basamaklarına 1'er etkinlikte yer verildiği; çözümleme, değerlendirme ve yaratma basamaklarına ise etkinliklerde yer verilmediği görülmektedir. Bu metinde yer alan ve değerlendirme basamağına uygun olduğu düşünülen bir etkinlik örneği aşağıda verilmiştir.

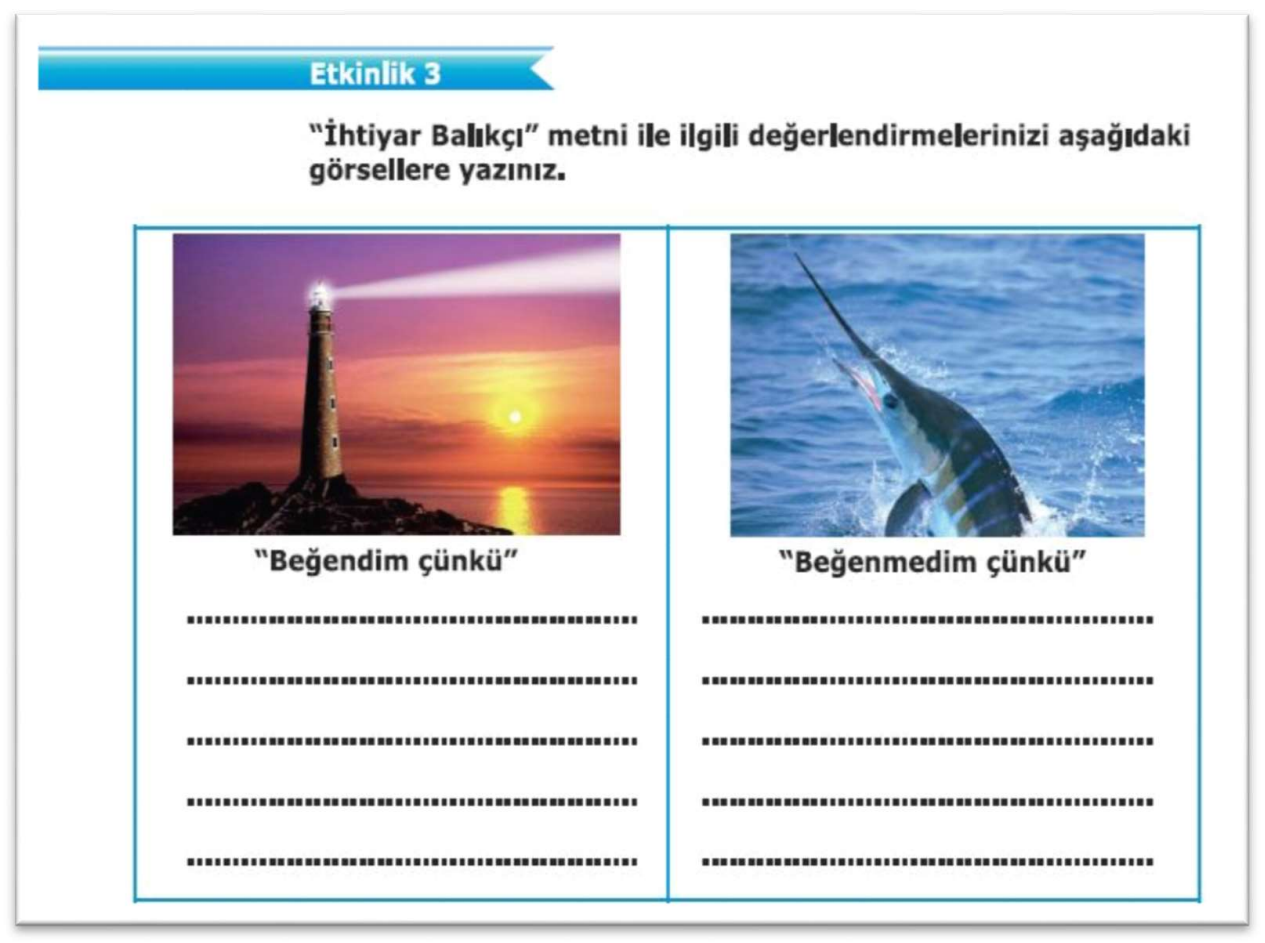

Tablo 16. "Dost Bildiklerim” metni etkinliklerinin Yenilenmiş Bloom Sınıflandırması'na göre dağılımı

\begin{tabular}{|c|c|c|c|c|c|c|c|}
\hline & $\begin{array}{l}\text { Etkinlik } \\
\text { No }\end{array}$ & Hatırlama & Anlama & Uygulama & Çözümleme & Değerlendirme & Yaratma \\
\hline \multirow{5}{*}{ 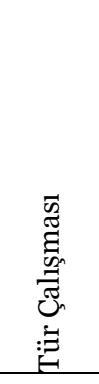 } & 1 & $\sqrt{ }$ & $\sqrt{ }$ & & & & \\
\hline & 2 & $\sqrt{ }$ & & & & & \\
\hline & 3 & & $\sqrt{ }$ & & & & \\
\hline & 4 & & & & & & $\checkmark$ \\
\hline & 5 & & $\sqrt{ }$ & & & & \\
\hline \multirow{3}{*}{ 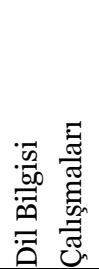 } & 1 & $\sqrt{ }$ & & $\sqrt{ }$ & & & \\
\hline & 2 & $\sqrt{ }$ & & & & & \\
\hline & 3 & $\sqrt{ }$ & & & & & \\
\hline
\end{tabular}


Tablo 16 incelendiğinde "Dost Bildiklerim” okuma metninde 8 etkinliğin yer aldı̆̆ ve bu etkinliklerde hatırlama basamağına 5 , anlama basamağına 3, uygulama ve yaratma basamaklarına 1'er etkinlikte yer verildiği; çözümleme ve değerlendirme basamaklarına ise etkinliklerde yer verilmediği görülmektedir. $\mathrm{Bu}$ metinde yer alan ve hatırlama basamağına uygun olduğu düşünülen bir etkinlik örneği aşağıda verilmiştir.

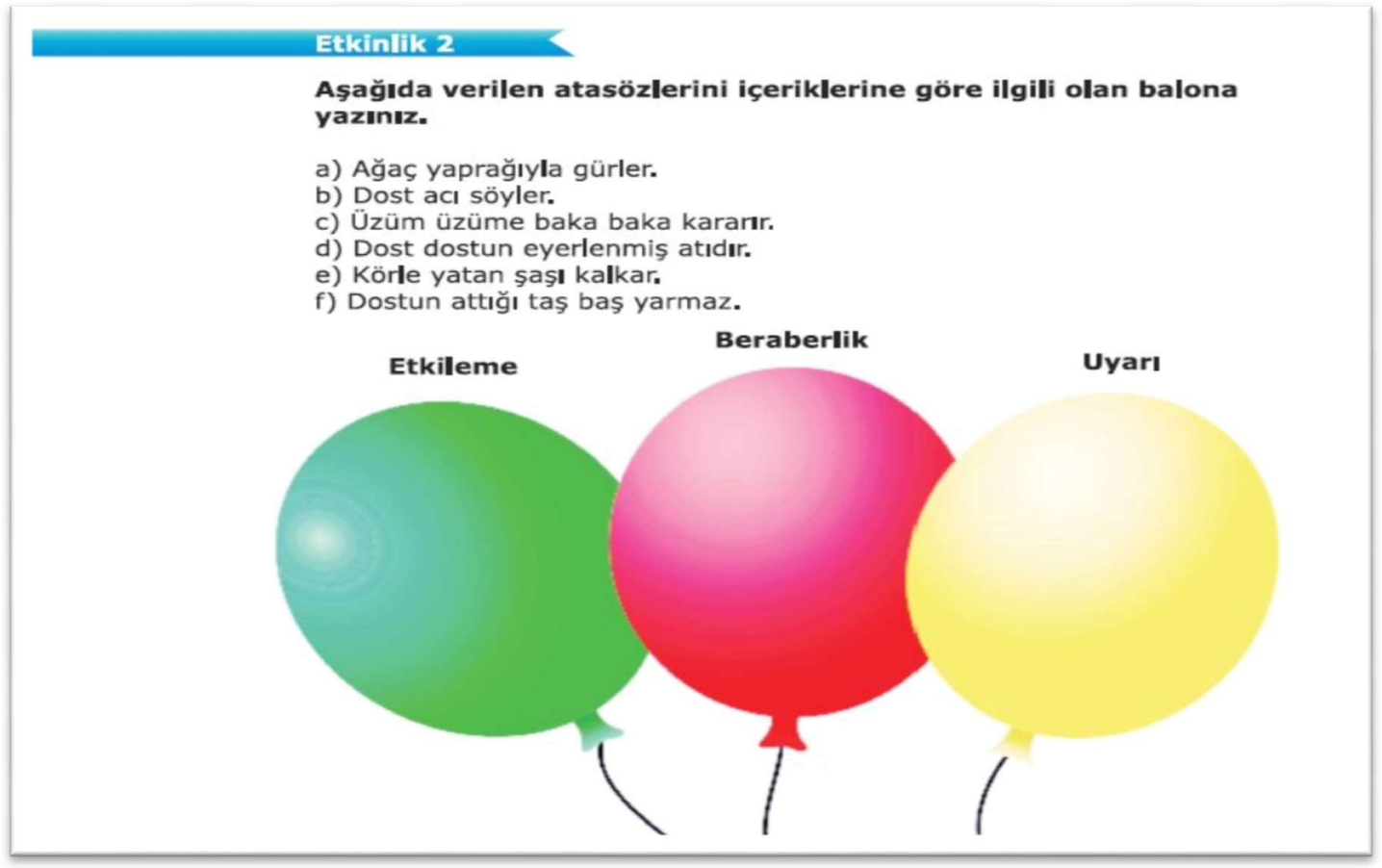

Tablo 17. "Güler Yüz” metni etkinliklerinin Yenilenmiş Bloom Sınıflandırması’na göre dağılımı

\begin{tabular}{|c|c|c|c|c|c|c|c|}
\hline & $\begin{array}{l}\text { Etkinlik } \\
\text { No }\end{array}$ & Hatırlama & Anlama & Uygulama & Çözümleme & Değerlendirme & Yaratma \\
\hline \multirow{5}{*}{ 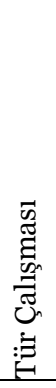 } & 1 & & & & & $\sqrt{ }$ & \\
\hline & 2 & & & & & & $\sqrt{ }$ \\
\hline & 3 & $\sqrt{ }$ & & & & & \\
\hline & 4 & & $\sqrt{ }$ & & & & \\
\hline & 5 & & $\sqrt{ }$ & & & & $\sqrt{ }$ \\
\hline \multirow{3}{*}{ 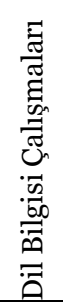 } & 1 & $\sqrt{ }$ & & & & & \\
\hline & 2 & $\sqrt{ }$ & & & & & \\
\hline & 3 & $\sqrt{ }$ & & $\sqrt{ }$ & & & \\
\hline
\end{tabular}

RumeliDE Dil ve Edebiyat Araşttrmalar Dergisi Osmanağa Mahallesi, Mürver Çiçeği Sokak, No:14/8 Kadıköy - ISTANBUL / TÜRKIYE 34714 e-posta: editor@rumelide.com tel: +90 $5057958124,+902167730616$
Address

RumeliDE Journal of Language and Literature Studies Osmanağa Mahallesi, Mürver Çiçeği Sokak, No:14/8

Kadıköy - ISTANBUL / TURKEY 34714

e-mail: editor@rumelide.com,

phone: +90 505 7958124, +90 2167730616 
Tablo 17 incelendiğinde "Güler Yüz" okuma metninde 8 etkinliğin yer aldı̆̆ı ve bu etkinliklerde hatırlama basamağına 4, anlama ve yaratma basamaklarına 2'şer, uygulama ve değerlendirme basamaklarına 1'er etkinlikte yer verildiği; çözümleme basamağına ise etkinliklerde yer verilmediği görülmektedir. Bu metinde yer alan ve değerlendirme basamağına uygun olduğu düşünülen bir etkinlik örneği aşağıda verilmiştir.

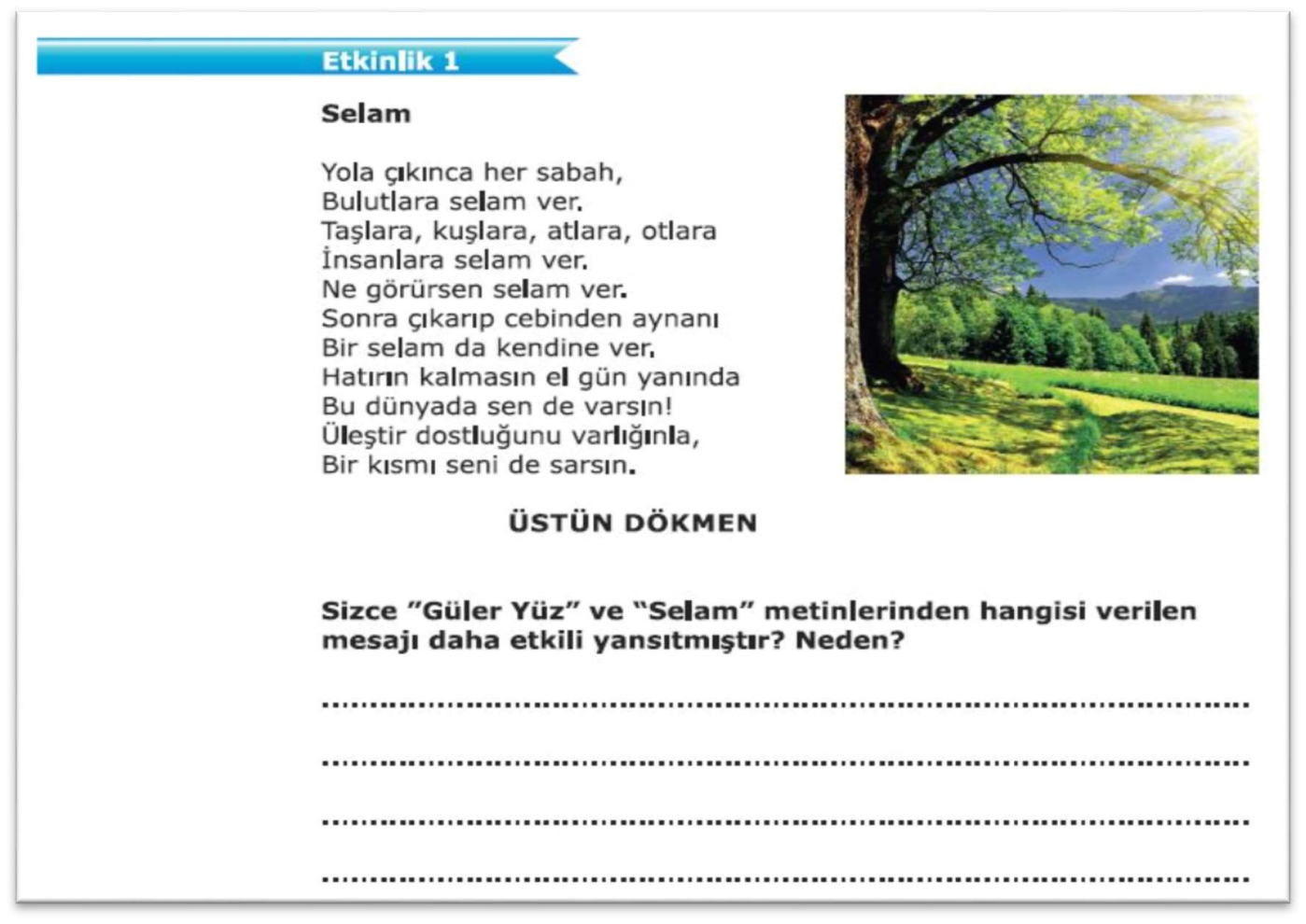

Tablo 18. KKTC 6. sınıf Türkçe ders kitabındaki toplam etkinlik sayısı ve bu etkinliklerin Yenilenmiş Bloom Sinıflandırması'na göre dağılımı

\begin{tabular}{llllllll}
\hline & $\begin{array}{l}\text { Etkinlik } \\
\text { Sayısı }\end{array}$ & Hatırlama & Anlama & Uygulama & Çözümleme & Değerlendirme & Yaratma \\
\hline $\begin{array}{l}\text { Tür } \\
\text { Çalışması }\end{array}$ & 57 & 24 & 19 & 9 & - & 3 & 15 \\
\hline $\begin{array}{l}\text { Dil Bilgisi } \\
\text { Çalışmaları }\end{array}$ & 38 & 32 & 6 & 11 & - & - & - \\
\hline Toplam & 95 & 56 & 25 & 20 & - & 3 & 15 \\
\hline
\end{tabular}

Tablo 18 incelendiğinde KKTC 6. sınıf Türkçe ders kitabında toplam 95 etkinliğin yer aldığı ve bunlardan 57'sinin tür çalışmasına, 38 'inin ise dil bilgisi çalışmalarına yönelik olduğu görülmektedir. Etkinliklerin Yenilenmiş Bloom Sınıflandırması'na göre dağılımı incelendiğinde hem tür hem de dil bilgisi çalışmalarının büyük kısmının hatırlama basamağına uygun olduğu ve çözümleme basamağına ise uygun hiçbir etkinliğin olmadığı görülmektedir.

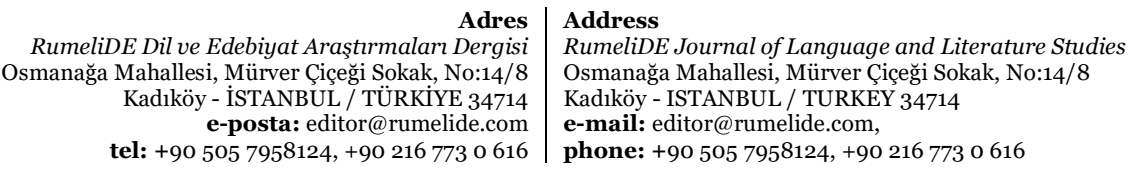




\section{Sonuç, tartışma ve öneriler}

KKTC Türkçe ders kitaplarındaki etkinliklerin Yenilenmiş Bloom Sınıflandırması'na göre incelenmesinin amaçlandığı bu çalışmada çeşitli sonuçlara ulaşılmıştır. Çalışmada KKTC 6. sınıf Türkçe ders kitabındaki 95 etkinlik detaylı şekilde analiz edilmiştir. 95 etkinliğin bazılarının Bloom Sınıflandırması’nın sadece bir basamağına uygun bazılarının birden fazla basamağa uygun olduğu tespit edilmiştir.

Ders kitabındaki etkinliklerin büyük kısmının (\%84. 87) “alt düzey bilişsel beceri basamakları”na, çok az bir kısmının da (\%15. 13) “üst düzey bilişsel beceri basamakları”na uygun olduğu saptanmıştır. Bu da etkinliklerin dengeli bir şekilde dağılmadığını göstermektedir. Oryaşın (2021: 820) Türkiye'deki Türkçe ders kitaplarındaki (1-8. sınıf) etkinlikleri Yenilenmiş Bloom Sınıflandırması'na göre incelediği çalışmasında Türkçe ders kitaplarındaki etkinliklerin daha çok (\%75. 53) alt düzey bilişsel becerileri karşıladığını tespit etmiştir. İlgili çalışmanın dışında alanyazında benzer araştırmalar da Türkiye'deki Türkçe ders kitaplarında yer alan etkinliklerin Yenilenmiş Bloom Sınıflandırması'na göre dengeli dağılmadığını göstermektedir (Sarar Kuzu, 2013; Eroğlu ve Sarar Kuzu, 2014; Dolunay ve Savaş, 2016; Ulum, 2017; Durukan ve Demir, 2017; Kıyagan, 2019; Eroğlu, 2019; Karakaş Yıldırım, 2020; Sallabaş ve Yllmaz, 2020).

Türkiye'deki Türkçe Dersi Öğretim Programlarında (2006, 2015 ve 2018 Türkçe Öğretim Programları) ve KKTC Türkçe Dersi Öğretim Programı'nda (2016) üst düzey düşünebilen, etkin öğrenme becerisine sahip, problem çözme becerisi gelişmiş öğrencilerin yetiştirilmesinin hedeflendiği vurgulanmaktadır. $\mathrm{Bu}$ hedefin ders kitaplarına yansıtılması da beklenmektedir. Ancak hem bu çalışmanın hem de yukarıda ifade edilen çalışmaların sonuçları irdelendiğinde ilgili hedefin ders kitaplarına istenilen düzeyde yansitılmadığı söylenebilir.

Üst düzey düşünme becerilerinin gelişimi uzun bir zaman diliminde gerçekleşmekte, öğretim faaliyetlerinin üst düzey düşünme becerilerine odaklanması gerekmektedir (Tuncer, 2010: 49). KKTC 6 . sınıf Türkçe ders kitabındaki etkinliklerde bu bağlamda bir sonuca ulaşılmadığı saptanmıştır. Aynı şekilde Türkiye'deki Türkçe ders kitaplarındaki etkinliklerin de üst düzey zihinsel becerileri ölçme bakımından tüm sınıf düzeylerinde yetersiz kaldığı ve alt düzey zihinsel beceri gerektiren etkinliklerde yoğunlaştığı (Ulum ve Taşkaya, 2019: 116) tespit edilmiştir. Eğitim - öğretimin birden fazla değişkenden oluştuğu düşünüldüğünde üst düzey düşünme becerilerine sadece ders kitaplarında yer alan etkinliklerde değil diğer unsurlarda da yeteri düzeyde yer verilmediği görülmektedir. Nitekim Akyol (2001) çalışmasında ilköğretim okulları 5. sınıf Türkçe kitaplarındaki okuma metinleriyle ilgili soruların analizini yapmış ve okuma metinleriyle ilgili soruların büyük kısmının öğrencileri ezbere yönlendirdiğini saptamıştır. Başka bir çalışmada da (Güfta ve Zorbaz, 2008) ilköğretim ikinci kademe Türkçe derslerinde kullanılan yazılı sınav soruları değerlendirilmiş ve bu soruların büyük oranda alt bilişsel düzeylerde sorular olduğu tespit edilmiştir. Bu bağlamda öğretim programlarında ifade edilen ve öğrencilerin gelişiminde büyük önem taşıyan üst düzey düşünme becerilerinin yeterli düzeyde gelişmesi için ders kitaplarındaki metinler, etkinlikler ve sınavların uyumlu olması son derece önemlidir. Çünkü "üst düzey düşünme becerilerini edinmiş öğrenciler, karşılaştıkları sorunları akılcı yollarla çözebilir, doğru kararlar verir ve özdüzenleme yaparlar” (Aslan, 2010).

KKTC Türkçe ders kitaplarındaki etkinliklerin daha çok hatırlama, anlama ve uygulama basamaklarına yönelik olması bu etkinliklerin daha çok metni anlamaya yönelik tür çalışması ve dil bilgisi çalışmaları biçiminde olmasıyla açıklanabilir. Nitekim Eroğlu (2013) çalışmasında dil bilgisi etkinliklerini Bloom

\footnotetext{
Adres $\mid$ Address

RumeliDE Dil ve Edebiyat Araştırmaları Dergisi $\quad$ RumeliDE Journal of Language and Literature Studies Osmanağa Mahallesi, Mürver Çiçeği Sokak, No:14/8 $\quad$ Osmanağa Mahallesi, Mürver Çiçeği Sokak, No:14/8 Kadıköy - ISTANBUL / TURKIYE 34714 Kadıköy - ISTANBUL / TURKEY 34714 e-posta: editor@rumelide.com e-mail: editor@rumelide.com, tel: +90 505 7958124, +90 2167730616 phone: +90 505 7958124, +90 2167730616
} 
Sınıflandırması'na göre incelemiş ve çalışmasında dil bilgisi etkinliklerinin alt düzey bilişsel becerilere uygun olduğunu, üst düzey bilişsel basamağa hiçbir etkinliğin uygun olmadığını saptamıştır. Karakaş Yıldırım (2020: 315) da 8. sınıf Türkçe ders kitabındaki yazma etkinliklerini Yenilenmiş Bloom Sınıflandırması'na göre incelediği çalışmasında etkinliklerin büyük kısmının alt düzey bilişsel becerilere uygun olduğunu bulgulamıştır. Çözümleme, değerlendirme basamaklarına uygun etkinlik sayısının ise son derece yetersiz olduğu tespit edilmiştir. Özellikle çözümleme basamağına uygun herhangi bir etkinliğin olmaması dikkat çekici bir göstergedir. "Çözümleme ve değerlendirme basamağı düzeyinde yer alan etkinlikler, öğrencilerin eleştirel düşünmelerini ve kestirimlerde bulunmalarını gerektirir. Böylece öğrencilerin derinlemesine çözümleme yapmaları ve düşüncelerini dile getirmeleri beklenir. Genellikle bu tür etkinliklerin birden çok yanıtı vardır ve öğrencilerin kendi düşüncelerini kullanarak çözüm yollarını bulmaları sağlanır.” Oryaşın (2021: 829) Öğrencilerin düşünme becerilerinin geliştirilmesi gerektiği düşünüldüğünde Türkçe ders kitaplarında bu basamaklara uygun etkinliklere daha fazla yer verilmesi gerektiği söylenebilir. Etkinliklerin üst düzey bilişsel beceriler arasında nispeten uygun olduğu basamak yaratma basamağıdır. "Yaratıcılık söz konusu olduğunda; bilgi ve deneyim birikiminden yararlanarak sentezleme sonucu yeni ürünler ortaya koymak gerekir” (Temizyürek ve Bulut, 2016: 151). Yaratıcılık hem ana dili eğitiminin hem de temel dil becerilerinin gelişiminde son derece önemlidir. Çünkü öğrencilerin duygu ve düşüncelerinin en iyi anlaşıldığı basamak yaratıcılıktır. $\mathrm{Bu}$ bağlamda Türkçe ders kitaplarında yaratıcılık becerisini geliştiren etkinliklere daha fazla yer verilmesi gerekir.

Çalışmada ulaşılan bulgular sonucunda; KKTC'de okutulan diğer sınıf düzeylerindeki Türkçe ders kitaplarının benzer şekilde incelenmesi ve bütüncül bir sonuca ulaşılması, öğretim programlarında hedeflenen üst düzey düşünme becerilerinin geliştirilmesi için Türkçe ders kitaplarındaki etkinliklerde üst düzey bilişsel beceri basamaklarına uygun daha fazla etkinliğe yer verilmesi gerektiği önerilmektedir.

\section{Kaynakça}

Akyol, H. (2001). İlköğretim okulları 5. sınıf Türkçe kitaplarındaki okuma metinleriyle ilgili soruların analizi. Kuram ve Uygulamada Ĕ̆itim Yönetimi, 7(2), 169-178.

Amer, A. (2006). Reflections on Bloom's revised taxonomy. Electronic Journal of Research in Educational Psychology, 4(1), 213-230.

Anderson, L. W. \& Krathwohl, D. R. (Eds.) (2001). A Taxonomy for learning teaching and assessing. a revision of Bloom's taxonomy of educational objectives. New York: Longman.

Arı, A. (2011). Bloom ' un gözden geçirilmiş bilişsel alan taksonomisinin Türkiye ' de ve uluslararası alanda kabul görme durumu. Kuram ve Uygulamada Eğitim Bilimleri, 11(2), 749-772.

Aslan, C. (2010). Düşünme becerilerini geliştirici dil ve edebiyat öğretimi ortamları -Bir eğitim durumu örneği-. Bahkesir Üniversitesi Sosyal Bilimler Enstitüsü Dergisi, 13(24), 127-152.

Ayvacı, H. S. \& Türkdoğan, A. (2010).Yeniden yapılandırılan Bloom taksonomisine göre fen ve teknoloji dersi yazılı sorularının incelenmesi. Türk Fen Ĕ̆itimi Dergisi, 7(1), 13-25.

Başbay, M. (2008). Yenilenmiş taksonomiye göre düzenlenmiş öğretim tasarımı dersinde projeye dayalı öğretimin öğrenme ürünlerine etkisi. Yayımlanmış Doktora Tezi, Ankara: Hacettepe Üniversitesi.

Bekdemir, M. \& Selim, Y. (2008). Revize edilmiş Bloom taksonomisi ve cebir öğrenme alanı örneğinde uygulaması. Erzincan Eğitim Fakültesi Dergisi, 1O(2), 185-196.

Beyreli, L., Sönmez, H. (2017). Bloom taksonomisi ve yenilenmiş Bloom taksonomisi ile ilgili Türkiye'de yapılan çalışmaların odaklandığı araştırma konuları. International Journal of Languages' Education and Teaching, 5(2), 213-229.

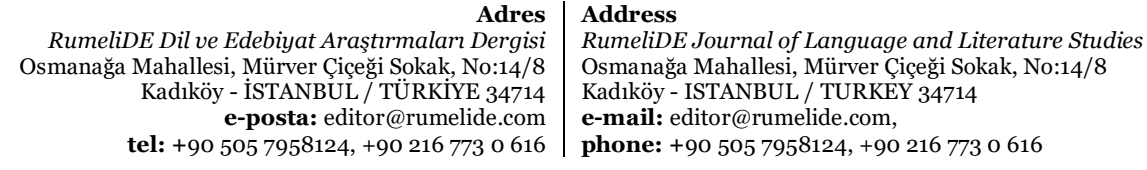


Bloom, B. S., Engelhart, M. D., Furst, E. J., Hill, W. H. \& Krathwohl, D. R. (1956). Taxonomy of educational objectives: The classification of educational goals. Handbook I: Cognitive Domain. (B. S. Bloom, Ed.). New York: McKay.

Bümen, N. T. (2006). Program Geliştirmede Bir Dönüm Noktası: Yenilenmiş Bloom Taksonomisi, Ĕ̆itim ve Bilim, 31 (142), s. 3-14.

Bümen, N. T. (2007). Effects of the original versus revised Bloom's taxonomy on lesson planning skills: A Turkish study among pre-service teachers, Review of Education, 53, 439-455.

Creswell, J. W. (2005). Educational Research: Planning, Conducting And Evaluating Quantitative and Qualitati And Research. USA: Pearson Prentice Hall.

Çepni, S. (2012). Araştırma ve proje çalışmalarına giriş. Trabzon: Celepler Matbaacılık.

Demir, P. (2015). Yenilenmiş Bloom taksonomisine göre 2005 yllı Sosyal Bilgiler öğretim programında yer alan kazanımlar ve seviye belirleme sınav soruları. Yayımlanmamış Yüksek Lisans Tezi, Samsun: On Dokuz Mayıs Üniversitesi.

Dolunay, S. K. ve Savaş, Ö. (2016). Ortaokul Türkçe ders kitaplarındaki dinleme etkinliklerinin üst düzey bilişsel beceriler açısından değerlendirilmesi. Eğitimde Kuram ve Uygulama, 12(1), 122-157.

Durukan, E. ve Demir, E. (2017). 6, 7 ve 8. sınıf Türkçe dersi öğrenci çalışma kitaplarındaki etkinliklerin Bloom'un yenilenmiş taksonomisine göre sınıflandırılması. Uluslararası Türkçe Edebiyat Kültür Ĕ̆itim Dergisi, 6(3), 1619-1629.

Eroğlu, D. (2013). 6., 7. ve. 8. sınıf Türkçe çalışma kitaplarındaki dil bilgisi soruları ve kazanımlarının yenilenmiş Bloom taksonomisine göre değerlendirilmesi. Yayımlanmamış Yüksek Lisans Tezi, Ankara: Başkent Üniversitesi.

Eroğlu, D. ve Sarar Kuzu, T. (2014). Türkçe ders kitaplarındaki dilbilgisi kazanımlarının ve sorularının yenilenmiş Bloom taksonomisine göre değerlendirilmesi. Başkent University Journal of Education, 1(1), 72-80.

Eroğlu, S. (2019). 6. sınıf Türkçe ders kitaplarındaki metin altı okuma-anlama soru ve etkinliklerinin Güncellenmiş Bloom Taksonomisi’ne göre değerlendirilmesi. Yayımlanmamış Yüksek Lisans Tezi, Balıkesir: Balıkesir Üniversitesi.

Karakaş Yıldırım, Ö. (2020). 8. sınıf Türkçe ders kitabındaki yazma etkinliklerinin yenilenmiş Bloom taksonomisine göre incelenmesi. Ana Dili Ĕ̆itimi Dergisi, 8(2), 315-325.

Karasar, N. (2007). Bilimsel araştırma yöntemi. Ankara: Nobel Yayın Dağıtım.

Kıyagan, H. G. (2019). 5, 6 ve 7. sinff Türkçe ders kitaplarındaki etkinliklerin yenilenmiş Bloom sınıflamasına göre yaratıcıllk açısından değerlendirilmesi. Yayımlanmamış Yüksek Lisans Tezi, İstanbul: Bahçeşehir Üniversitesi.

KKTC Millî Eğitim ve Kültür Bakanlığı. (2016). Temel Eğitim Türkçe Dersi 1-8. Sinıflar Öğretim Programı

Krathwohl, D. R. (2002). A Revision of Bloom's taxonomy: an overview. Theory Into Practice, 41(4), 212-218.

MEB. (2006). İlköğretim Türkçe dersi (6, 7, 8. sinıflar) öğretim programı. Ankara: Millî Eğitim Bakanlığı Yayınları.

MEB. (2015). MEB Türkçe dersi (1- 8. sinfflar) öğretim programı. Ankara: MEB Devlet Kitapları Müdürlüğü.

MEB. (2018). MEB Türkçe dersi (1-8. sımıflar) öğretim programı. Ankara: MEB Devlet Kitapları Müdürlüğ̈̈.

Miles, M. B. ve Huberman, A. M. (2015). Genişletilmiş bir kaynak kitap nitel veri analizi. [Çev. Ed. S. Akbaba Altun - A. Ersoy (Giriş Bölümünü Çev. A. Ç. Kılınç)]. Ankara: Pegem Akademi.

Oryaşın, U. (2021). Türkçe ders kitaplarındaki etkinliklerin Yenilenen Bloom Sınıflandırması'na göre incelenmesi. Ana Dili Ĕ̆itimi Dergisi, 9(3), 820-832.

$$
\begin{aligned}
& \begin{array}{r|l}
\text { Adres } & \text { Address } \\
\text { RumeliDE Dil ve Edebiyat Araştırmaları Dergisi } & \text { RumeliDE Journal of Language and Literature Studies }
\end{array} \\
& \text { Osmanağa Mahallesi, Mürver Çiçeği Sokak, No:14/8 } \quad \text { Osmanağa Mahallesi, Mürver Çiçeği Sokak, No:14/8 } \\
& \text { Kadıköy - ISTANBUL / TURKIYE } 34714 \text { Kadıköy - ISTANBUL / TURKEY } 34714 \\
& \text { e-posta: editor@rumelide.com e-mail: editor@rumelide.com, } \\
& \text { tel: +90 505 7958124, +90 } 2167730616 \text { phone: +90 505 7958124, +90 } 2167730616
\end{aligned}
$$


Sallabaş, M. E. ve Yılmaz, G. (2020). Türkçe ders kitabı'nda bulunan metin altı sorularının yenilenmiş Bloom Taksonomisi'ne göre incelenmesi. Ana Dili Eğitimi Dergisi, 8(2), 586-596. DOI: 10.16916/aded.679933.

Sarar Kuzu, T. (2013). Türkçe ders kitaplarındaki metin altı sorularının yenilenmiş Bloom taksonomisindeki hatırlama ve anlama bilişsel düzeyleri açısından incelenmesi. Cumhuriyet Üniversitesi Edebiyat Fakültesi Sosyal Bilimler Dergisi, 37(1), 58-76.

Temizyürek, F. \& Bulut, K. (2016). Çocuğun Dil Gelişiminde Yaratıcı Yazmanın Önemi. Yüzüncü Yıl Üniversitesi Eğitim Fakültesi Dergisi, 13(1), 146-163.

Tuncer, Ö. Ç. (2010). Türkçe Dersinde Üst Düzey Düşünme Becerilerinin Geliştirilmesi. Cito Eğitim: Kuram ve Uygulama İnternet'ten 8 Kasım 2021'de http://www.ogretmen.info/makale/23.pdf adresinden alınmıştır.

Ulum, H. (2017). MEB ilkokul 2, 3 ve 4. sinıf Türkçe ders ve çalsşma kitaplarında yer alan etkinliklerin yenilenmiş Bloom taksonomisine göre incelenmesi. Yayımlanmamış Yüksek Lisans Tezi, Mersin: Mersin Üniversitesi.

Ulum, H., \& Taşkaya, S.M. (2019). İlkokul 2, 3 ve 4. Sınıf Türkçe ders ve çalışma kitaplarında yer alan etkinliklerin yenilenmiş bloom taksonomisine göre incelenmesi. Kastamonu Education Journal, 27(1), 107-118. doi:10.24106/kefdergi.2380

Wineburg, S. \& Schneider, J. (2013). Was Bloom's taxonomy pointed in the wrong direction? Bloom taksonomisi yanlış yönü mü işaret etti? Turkish History Education Journal, 2(2), 228-239.

Yeşilyurt, E. (2012). Öğretmen adaylarının bilişsel alanla ilgili sınama durumu soruları yazma yeterliklerinin değerlendirilmesi. Kastamonu Ĕ̆itim Dergisi, 2o(2), 519-530.

Yıldırım, A. ve Şimşek, H. (2008). Sosyal bilimlerde nitel araştırma yöntemleri. Ankara: Seçkin.

RumeliDE Dil ve Edebiyat Araştırmaları Dergisi Osmanağa Mahallesi, Mürver Çiçeği Sokak, No:14/8 Kadıköy - İSTANBUL / TÜRKIYE 34714 e-posta: editor@rumelide.com tel: +90 $5057958124,+902167730616$
Address

RumeliDE Journal of Language and Literature Studies Osmanağa Mahallesi, Mürver Çiçeği Sokak, No:14/8

Kadıköy - ISTANBUL / TURKEY 34714

e-mail: editor@rumelide.com,

phone: +90 $5057958124,+902167730616$ 